Elsevier Editorial System(tm) for Fungal Genetics and Biology

Manuscript Draft

Manuscript Number: FGB-08-111R1

Title: Annotation of stress-response proteins in the aspergilli

Article Type: Aspergillus Themed Issue

Keywords: Aspergillus; stress response; mitogen-activated protein kinase; Environmental Stress Response; comparative genomics; genome annotation; osmotic stress; oxidative stress; thermal stress; Unfolded

Protein Response; starvation stress; DNA repair; Saccharomyces cerevisiae; Schizosaccharomyces pombe; Neurospora crassa; HOG pathway

Corresponding Author: Dr. István Pócsi,

Corresponding Author's Institution: University of Debrecen

First Author: Márton Miskei

Order of Authors: Márton Miskei; Zsolt Karányi; István Pócsi

Abstract: Stress-response proteins of Aspergillus nidulans, A. clavatus, A. flavus, A. fumigatus, A. niger, A. oryzae, A. terreus and Neosartorya fischeri (3908 in total) were annotated and grouped according to stress types (http://193.6.155.82/AspergillusStress/). All genomes harboured elements of the SskA - HogA/SakA stress signalling pathway. There are accumulating data pointing at the importance of SskA - HogA/SakA signalling in different types of stress-responses in the aspergilli and, in this regard, these filamentous fungi are closer to fission yeast than to budding yeast. The abundance of annotated stress sensing histidine kinases and transcriptional regulators in each Aspergillus species indicates that the applicability of yeastbased models to fully describe and explain the stress-responses of these fungi is limited. Most excitingly, putative orthologues of both S. cerevisiae Msn2p/Msn4p C2H2 zinc finger-type and S. pombe Atf1 bZip-type 'general stress' transcription factors were annotated in the aspergilli, foreshadowing complex and robust stress defence systems in these euascomycetes. 


\title{
Annotation of stress-response proteins in the aspergilli
}

\author{
Márton Miskei $^{\text {a,b,\#, Zsolt Karányi }}{ }^{\mathrm{c}, \#}$ and István Pócsi ${ }^{\mathrm{a}, *}$
}

a - Department of Microbial Biotechnology and Cell Biology, Faculty of Science and Technology, University of Debrecen, H-4010 Debrecen, Hungary

b - Department of Horticulture and Plant Biotechnology, Faculty of Agricultural Science, University of Debrecen, H-4010 Debrecen, Hungary

c - First Department of Medicine, Faculty of Medicine, University of Debrecen, H-4012 Debrecen, Hungary

* - Corresponding author:

Department of Microbial Biotechnology and Cell Biology, Faculty of Science and Technology, University of Debrecen, P.O.Box 63, H-4010 Debrecen, Hungary; Tel: 36-52512900 ext. 62337, Fax: 36-52-512925, E-mail: istvanpocsi@yahoo.com

\# - These two authors contributed equally to this paper. 


\begin{abstract}
Stress-response proteins of Aspergillus nidulans, A. clavatus, A. flavus, A. fumigatus, A. niger, A. oryzae, A. terreus and Neosartorya fischeri (3908 in total) were annotated and grouped according to stress types (http://193.6.155.82/AspergillusStress/). All genomes harboured elements of the SskA - HogA/SakA stress signalling pathway. There are accumulating data pointing at the importance of SskA - HogA/SakA signalling in different types of stressresponses in the aspergilli and, in this regard, these filamentous fungi are closer to fission yeast than to budding yeast. The abundance of annotated stress sensing histidine kinases and transcriptional regulators in each Aspergillus species indicates that the applicability of yeastbased models to fully describe and explain the stress-responses of these fungi is limited. Most excitingly, putative orthologues of both $S$. cerevisiae Msn2p/Msn4p C2H2 zinc finger-type and S. pombe Atf1 bZip-type 'general stress' transcription factors were annotated in the aspergilli, foreshadowing complex and robust stress defence systems in these euascomycetes.
\end{abstract}




\section{Introduction}

Comparative genome analysis is flourishing in the aspergilli (Jones, 2007) with four genome sequences published (Aspergillus nidulans, a filamentous fungus model organism, Galagan et al., 2005; Aspergillus fumigatus, the most common species among the aspergilli causing human infections, Nierman et al., 2005; Aspergillus oryzae, a species traditionally used in the Japanese and Chinese cuisines to ferment food, Machida et al., 2005; Aspergillus niger, an industrial organic acid and enzyme producer, Pel et al., 2007) and four others assembled and annotated (Aspergillus clavatus, a patulin producer close relative of A. fumigatus, Wortman et al., 2006; Aspergillus flavus, an aflatoxin producer and opportunistic pathogen fungus, Payne et al., 2006; Aspergillus terreus, a source of the serum cholesterol lowering compound lovastatin, Wortman et al., 2006, Neosartorya fischeri (teleomorph of Aspergillus fischerianus), a soil-inhabiting close relative of A. fumigatus, Wortman et al., 2006). A most recent comparative genomic study on the opportunistic human pathogenic fungus $A$. fumigatus and two closely related, rarely pathogenic species $N$. fischeri and A. clavatus led to the identification of genomic islands in the pathogen, which function as designated gene dumps and gene factories (Fedorova et al., 2008). Other comparative genomics studies shed light on mating process genes in A. oryzae and A. fumigatus (Galagan et al., 2005; Nierman et al., 2005), the gliotoxin gene cluster in A. fumigatus (Gardiner and Howlett, 2005), and elements of programmed cell death pathways in the aspergilli (Fedorova et al., 2005).

Free-living fungi often encounter different kinds of environmental stress including changes in osmolarity, temperature, availability of $\mathrm{O}_{2}$ and nutrients (Gasch, 2007). Pathogens are exposed to chronic oxidative stress caused by immune system cells (Fekete et al., 2007), and industrial fungi cope with stress coming from the technology employed, e.g. the use of elevated $\mathrm{O}_{2}$ pressure (Kubicek and Karaffa, 2006). A deeper understanding of stress signalling and regulation in filamentous fungi may help us to find new targets for future antifungal drug design (Rementeria et al., 2005; Meyer et al., 2007), to develop more stresstolerant and high producer industrial strains (Emri et al., 1997, 1999; MacKenzie et al., 2005; Pócsi et al., 2005), and to attenuate mycotoxin production (Pócsi et al., 2005; Kim et al., 2008). 
Environmental stress response (ESR) genes responding to diverse types of stress have been identified in Saccharomyces cerevisiae (Gasch et al., 2000; Causton et al., 2001) and Schizosaccharomyces pombe (Chen et al., 2003) but a common stress response is less obvious in the opportunistic and dimorphic human pathogen Candida albicans (Enjalbert et al., 2003; Gasch, 2007). Meanwhile stress signalling is stress-specific in budding yeast, e.g. the Hog1p MAPK signalling pathway is responsive to osmotic and related stress, Sty1 "all-purpose" MAPK pathway plays a pivotal role in stress signalling in S. pombe (Gasch et al., 2000; Causton et al., 2001; Chen et al., 2003; Gasch, 2007). Stress signalling pathways seem to converge at Msn2p/Msn4p and Atf1 "general stress" transcriptional factors in budding and fission yeasts, respectively, regulating similar groups of ESR genes (Gasch et al., 2000; Causton et al., 2001; Chen et al., 2003; Gasch, 2007).

In this study, we aim at the identification of Aspergillus orthologues of yeast stress adaptation proteins screening the genomes of eight Aspergillus spp. (A. nidulans, A. clavatus, A. flavus, A. fumigatus, A. niger, A. oryzae, A. terreus and N. fischeri). Moreover, we intend to compare the groups of stress-response proteins annotated for each Aspergillus to find species-specific elements. Finally, we discuss the hypothesis that Hog1p MAPK signalling is not limited to osmotic stress in the aspergilli (Kawasaki et al., 2002; Xue et al., 2004; Du et al., 2006; Hagiwara et al., 2007a) and may play a more common role in the orchestration of different stress responses similar to that of $S$. pombe Sty1 (Gasch, 2007).

\section{Materials and Methods}

Setting up databases. Databases were created including all proteins (and translated genes) that may play any role in stress response in yeasts and filamentous fungi. In the first database (Database No. 1), stress-response proteins were extracted from S. cerevisiae, S. pombe and $C$. albicans AMIGO databases (http://amigo.geneontology.org/cgi-bin/amigo/go.cgi). Following that Database No. 1 was supplemented with stress-response proteins of the filamentous fungi Neurospora crassa, A. flavus, A. fumigatus, A. nidulans, A. niger and A. oryzae. Filamentous fungus stress-response proteins were identified by web-search in PubMed (http://www.ncbi.nlm.nih.gov/sites/entrez) using the 'genus name+stress' and 'genus 
name+DNA repair' key word pairs, and protein sequences were collected through the weblinks found in the corresponding publications (http://www.ncbi.nlm.nih.gov/).

In the second database (Database No. 2), all putative proteins coming from A. nidulans translated ORFs were assessed using the Broad Institute Aspergillus nidulans database http://www.broad.mit.edu/annotation/genome/aspergillus_nidulans/Home.html. In Database No. 3, putative protein sequences available for S. cerevisiae (http://www.yeastgenome.org/), S. pombe (http://www.sanger.ac.uk/Projects/S_pombe/), C. albicans (http://www.candidagenome.org/), N. crassa (http://www.broad.mit.edu/annotation/genome/) and the aspergilli A. flavus, A. fumigatus, $A$. niger and $A$. oryzae (http://www.broad.mit.edu/annotation/genome/) were summarized (for genome sequencing and annotation of yeasts and filamentous fungi consult the papers of Cherry et al., 1997; Mewes et al., 1997; Ashburner et al., 2000; Wood et al., 2002; Galagan et al., 2003, 2005; Arnaud et al., 2005; Machida et al., 2005; Nierman et al., 2005; Aslett and Wood, 2006; Payne et al., 2006 and Pel et al., 2007).

Homology search and annotation of $A$. nidulans stress proteins. The following five-step protocol was employed:

- A. nidulans homologues of stress-response proteins were identified by BLASTP search program (Altschul et al., 1997; softwares used: blastall and formatdb downloaded from http://www.ncbi.nlm.nih.gov/Ftp) by comparing stress-response proteins from Database No. 1 to putative proteins in Database No. 2.

- Results were filtered according to the $1 \mathrm{E}-40$ (stands for $1 \times 10^{-40}$ ) expectation value $(E)$ cutoff criteria (Ayoubi et al., 2002; Xu et al., 2003; Poustka et al., 2003; Pócsi et al., 2005). The $E$-value is a parameter widely used for quantifying sequence similarities and assessing underlying biological relationships (Joshi and $\mathrm{Xu}, 2007$ ). In general, the lower the $E$-value, the more likely the homology and the biological relationship between the compared sequences (Joshi and $\mathrm{Xu}, 2007$ ).

- To reduce the number of mis-annotated proteins, sequences of candidate A. nidulans stressresponse proteins were compared to putative proteins in Database No. 3 using BLASTP protein sequences alignment.

- Results were filtered again at $E$-value 1E-40. 
- When the highest homology protein sequence found in the fourth step was identical to the protein we started the homology search with the result was accepted and discussed. In any other case, the outcome of the homology search was disregarded.

At last, A. nidulans orthologues were collated, characterized and grouped using Gene Ontology terms (Gene Ontology Consortium, 2001; Dwight et al., 2002; http://www.geneontology.org/; http://www.yeastgenome.org/) and supplemented with literature data found in species-specific genomic databases and NCBI PubMed (http://www.ncbi.nlm.nih.gov/sites/entrez).

Screening for stress-response proteins in the genus Aspergillus. All putative proteins translated from Aspergillus clavatus, A. flavus, A. fumigatus, A. nidulans, A. niger, A. oryzae, Aspergillus terreus and Neosartorya fischeri ORFs (Galagan et al., 2005; Machida et al., 2005; Nierman et al., 2005; Payne et al., 2006; Wortman et al., 2006, Pel et al., 2007) were assessed at http://www.broad.mit.edu/annotation/genome/aspergillus_group/MultiHome.html to set up Database No. 4. Stress-response proteins from Database No. 1 were compared to putative proteins in Database No. 4 with the sequence search program BLASTP. After filtering rough data using the $E \leq 1 \mathrm{E}-40$ cut-off criteria, candidate Aspergillus stress proteins and putative proteins in Database No. 3 were compared using BLASTP. Further annotation steps were the same as described above for A. nidulans stress-response proteins.

\section{Results}

A. nidulans special and Aspergillus generic stress databases are available at web links http://internal.med.unideb.hu/annota20070815/ (release date September 2007) and http://193.6.155.82/AspergillusStress/ (release date May 2008), respectively, and annotated $A$. nidulans stress-response proteins were also submitted to The J. Craig Venter Institute Aspergillus nidulans Annotation Database (http://www.tigr.org/; date of submission September 2007). Aspergillus stress-specific datasets are also linked directly to this paper (Supplementary Tables 1-8). In all stress databases and datasets presented in this paper, general information is given concerning annotated proteins (Aspergillus locus IDs) and their closest homologues in other species (stress gene locus IDs and protein names), stress type, 
gene ontology (GO) classes (GO IDs and GO descriptions), relevant publications (PMID IDs) and a brief functional characterization. Only stress-related GO terms were used to describe the function of annotated gene products to facilitate future computer-based data mining. In the Aspergillus stress database (http://193.6.155.82/AspergillusStress/), clicks on locus IDs and PMID IDs lead to the appropriate Broad Institute database entry and PubMed reference page, respectively.

The total number of annotated stress-response proteins in A. nidulans at $E \leq 1 \mathrm{E}-40$ comparison stringency is 486 (Supplementary Table 1), from which 133 takes part in osmotic stress, 108 in oxidative, 85 in thermal stress and unfolded protein, 37 in starvation stress responses, 172 in DNA repair processes and 73 in other stress responses (Table 1; Supplementary Table 1). Because only a very limited number of A. nidulans stress-response genes and gene products have been characterised satisfactorily thus far GO terms used for the description of orthologous yeast proteins are presented in Supplementary Table 1 even if the corresponding A. nidulans genes and/or proteins have already been published.

Considering other Aspergillus species, the numbers of putative stress response proteins were very similar to that found for A. nidulans, namely 484 for A. clavatus, 520 for A. flavus, 471 for A. fumigatus, 428 for A. niger; 503 for A. terreus, 515 for A. oryzae and 501 for $N$. fischeri. Altogether, 3908 Aspergillus stress-response proteins were annotated in this project. These data were also grouped according to functional categories and are summarized in Supplementary Tables 2-8.

A model of osmotic and oxidative stress response signalling and regulation in A. nidulans was set up collating annotation data presented in Supplementary Table 1 and relevant literature data published primarily for yeasts (Figure 1). Annotated elements of two-component His-toAsp phosphorelay stress signalling systems, down-stream MAPK regulatory pathways and elements of osmotic and oxidative stress defences are summarized for all aspergilli studied in Table 2. Putative A. nidulans orthologues with relatively low homology (1E-09 $>E>1 \mathrm{E}-40)$ to yeast osmotic and oxidative stress-response proteins are presented in Table 3. 


\section{Discussion}

\section{Osmotic and oxidative stress response proteins}

The great majority of putative stress response proteins of the aspergilli were annotated using yeast, primarily $S$. cerevisiae and $S$. pombe, data because our current knowledge on the stress response machinery of filamentous fungi is rather incomplete and mosaic-like in general. Not surprisingly, the organisation and regulation of stress sensing, signalling and response pathways in yeasts (Hohman 2002; O'Rourke et al., 2002; Chen et al., 2003; Saito and Tatebayashi 2004; Chauhan et al., 2006; Krantz et al., 2006a,b; Gasch et al., 2007) serve as a benchmark for the evaluation of stress response systems of other fungi. At first, we summarize the elements of osmotic and oxidative stress response in yeasts to make the presentation and discussion of Aspergillus stress protein annotation data easier and more effective.

High Osmolarity Glycerol (HOG) stress signalling and stress response in yeasts. Yeasts can sense and respond to high osmolarity stress via mitogen-activated protein kinase (MAPK) signalling systems (Table 2, Figure 1). In S. cerevisiae, Hog1p MAPK is activated by two independent upstream mechanisms. The first branch includes a two-component His-to-Asp phosphorelay system including $\operatorname{Sln} 1$ p histidine sensor kinase, Ypd1p histidine-containing phosphotransfer protein and Ssk1p and Skn7p response regulators (Posas et al., 1996; Li et al., 1998). In this pathway, the phosphorylation of Ssk1p prevents any interaction with Ssk2p/Ssk22p MAPKKK keeping the downstream elements of the Ssk2p/Ssk22p - Pbs2p Hog1p MAPK pathway inactive (Posas and Saito, 1998). Hyperosmotic stress inhibits Sln1p leading to the dephosphorylation of Ypd1p and Ssk1p, which facilitates Ssk1p Ssk2p/Ssk22p interactions and the activation of Hog1p (Posas and Saito, 1998).

The second branch includes the Sholp transmembrane sensor kinase, and the formation of Sho1p, Cdc42p, Ste20p/Cla4p, Ste50p, Ste11p (MAPKKK), Pbs2p (MAPKK) and Hog1p (MAPK) multi-component signalling complex (Saito and Tatebayashi 2004; Tatebayashi et al., 2006). The assembly of the complex includes the activation of Ste11p by Ste20p/Cla4p kinases by indirect docking via Ste50p (a SAM domain-containing protein) and Cdc42p (a small Rho-like GTPase), and the activation of Pbs2p by Ste11p by indirect docking via 
Ste50p adaptor and Sho1p (Tatebayashi et al., 2006). According to a recent publication of Tatebayashi et al. (2007), Hkrlp and Msb2p mucin-like transmembrane proteins are the potential osmosensors for the Sho1p branch of Hog1p activation.

Hog1p normally localizes in the cytoplasm in unstressed cells but translocates to the nucleus after phosphorylation in cells exposed to osmotic stress. Nuclear import of Hog1p requires the activity of Gsp1p small GTP-binding protein and the importin $\beta$ homologue Nmd5p (Ferrigno et al., 1998). Dephosphorylated Hog1p is exported from the nucleus to the cytoplasm by the nuclear exchange sequence receptor protein Crm1p (Ferrigno et al., 1998). Importantly, the Ypd1p phosphotransfer protein also needs to shuttle between the cytoplasm and the nucleus to phosphorylate the response regulators Ssk1p (cytoplasm) and Skn7p (nucleus) (Lu et al., 2003).

Dephosphorylation of $\operatorname{Hog} 1 \mathrm{p}$ is important to avoid the deleterious effects of the hyperactivation of this MAPK (Saito and Tatebayashi 2004). Important negative regulators are Ptp2p and Ptp3p protein phosphotyrosine phosphatases dephosphorylating Hog1p in both the nucleus (Ptp2p) and the cytoplasm (Ptp3p) (Mattison and Ota, 2000) and the protein phosphatase type 2C enzymes Ptc1p, Ptc2p and Ptc3p (Warmka et al., 2001; Young et al., 2002). Ptc1p dephosphorylates Hog1p via a docking interaction between Ptc1p, Hog1p, Pbs2p and the small adaptor protein Nbp2p (Mapes and Ota, 2004; Saito and Tatebayashi, 2004).

There are several different Hog1p-dependent activation mechanisms of osmotic stress regulated genes, including (i) the phosphorylation of Sko1p bZip-type repressor, which leads to the disassembly of Tup1p-Cyc8p(Ssn6p)-Sko1p repressor complexes and the activation of Sko1p (Proft et al., 2001), (ii) the Hot1p-dependent activation of the RNA polymerase II complex by Hog1p (Alepuz et al., 2003) and (iii) the Msn2p/Msn4p 'general stress' $\mathrm{C} 2 \mathrm{H} 2$ zinc finger transcription factors (Moskvina et al., 1998; Gasch et al., 2000, Causton et al., 2001; Gasch, 2007) dependent recruitment of Hog1p to osmotic stress responsive promoters (Reiser et al., 1999; Alepuz et al., 2001; Rep et al., 2000; O'Rourke et al., 2002). Importantly, the nuclear localization of Msn2p/Msn4p is independent of Hog1p and is regulated by protein kinase A (Görner et al., 1998). A group of stress-response genes, e.g. CTT1 encoding cytosolic catalase $\mathrm{T}$, is also regulated by the transcriptional activator Msn1p (Rep et al., 1999). 
Other Hog1p targets include Sgd1p nuclear protein (Akhtar et al., 2000; Lin et al., 2002) and the Smp1p transcription factor (de Nadal et al., 2003). The Rck2p protein kinase is a substrate of Hoglp and participates in $\mathrm{G}_{2}$ checkpoint control and the osmotic stress triggered attenuation of protein synthesis (Bilsland-Marchesan et al., 2000; Teige et al., 2001). In addition, Hog $1 p$ recruits Rpd3p histone deacetylase to induce gene expression on osmotic stress (de Nadal et al. 2004).

In S. pombe, a homologue of the Ssk2p/Ssk22p - Pbs2p - Hog1p MAPK kinase pathway does exist, which consists of Wak1/Win1 (MAPKKK) - Wis1 (MAPKK) - Sty1 (syn. Spc1) (MAPK) protein kinases (Figure 1). MAPK signalling is stimulated by a wide spectrum of environmental stress in addition to osmotic stress in this yeast (Shieh et al., 1997; Hohmann 2002; Chen et al., 2003; Gasch, 2007). The MAPK pathway is activated by a two-component His-to-Asp phosphorelay system including Mak1, Mak2 and Mak3 histidine kinases, Mpr1 phosphotransfer protein and Mcs4 response regulator, when cells are facing oxidative stress (Buck et al., 2001; Nakamichi et al., 2003). The sensor system for osmotic stress is not known yet (Hohmann, 2002) because fission yeast's genome does not accommodate either SLN1 or SHO1 orthologues (Krantz et al., 2006a). In fission yeast, the transcription factor Atf1 is a substrate of Sty1 (Shiozaki and Russel, 1996; Wilkinson et al., 1996), and phosphorylated Atf1 is a major key player in the induction of a wide spectrum of stress-responsive genes (ESR genes; Chen et al., 2003; Gasch, 2007; Sansó et al., 2008). Sty1 is dephosphorylated by Pyp1 and Pyp2 protein phosphotyrosine phosphatases (Millar et al., 1995) and, interestingly, Atf1 directly activates pyp2 gene completing a negative feed-back loop to phosphorylated Sty1 (Figure 1; Wilkinson et al., 1996). It is noteworthy that fission yeast does not have any orthologue of budding yeast's Msn2p/Msn4p transcription factors (Gasch, 2007).

Response regulators in addition to Ssk1p (S. cerevisiae) and Mcs4 (S. pombe) are Skn7p and Prr1 transcription factors, respectively, which are phosphorylated by Ypd1p (S. cerevisiae) and Mpr1 (S. pombe) phosphotransfer proteins. Skn7p is phosphorylated in the nucleus by Ypd1p (Lu et al., 2003). Skn7p and Prr1 govern the expression of an array of stressresponsive genes mainly required in oxidative stress defence (Krems et al., 1996; Ohmiya et al., 1999). It is noteworthy that $S k n 7 p$ response regulator and Yap1p bZip transcription factor co-operate in the induction of numerous oxidative stress responsive genes in budding yeast (Morgan et al., 1997). 
There are numerous stress-responsive genes under Hog1p (Sty1) control in yeasts including glycerol biosynthetic genes like GPDl (glycerol-3-phosphate dehydrogenase; Ansell et al., 1997) and GPP2 (glycerol-3-phosphatase; Boy-Marcotte et al. 1998), the glycerol transporter gene STL1 (de Nadal et al., 2003), ALD2 and CTT1 encoding cytoplasmic aldehyde dehydrogenase and cytosolic catalase T, respectively (Márquez et al., 1998), as well as P-type ATPase sodium pump genes like ENA1 and ENA2 (Garciadeblas et al., 1993) and pmp3 coding for a small membrane protein (Wang and Shiozaki, 2006).

Control by Skn7p (Prr1) response regulator in osmotic stress defence was demonstrated at genes cta3 (intracellular cation transporter; Greenall et al., 2002) and OCHI (mannosyltransferase of the cis-Golgi apparatus; Li et al., 2002) but its main function, together with Yap1p, is the regulation of oxidative stress defence genes like GPX2 (glutathione peroxidase; Tsuzi et al., 2004), CTT1 (cytosolic catalase T; He and Fassler, 2005), TRX2 and TRR1 (thioredoxin and thioredoxin reductase; Lee et al., 1999). In fission yeast, the expression of antioxidative genes like gpx1 and ctt1 is Atf1 and/or Pap1 (a Yap1p orthologue) transcription factor-dependent (Yamada et al., 1999; Nakagawa et al., 2000).

In the opportunistic human pathogenic dimorphic fungus, $C$. albicans, a functioning Ssk2pPbs2p-Hog1p MAPK signalling pathway was found, which transmits both osmotic and oxidative stress signals (Chauhan et al., 2003, 2006; Arana et al., 2005; Monge et al., 2006; Cheetham et al., 2007; Walia and Calderone, 2008). Meanwhile oxidative stress signals may be generated in two-component phosphorelay system consisting of a histidine kinase (SIn $1 \mathrm{p}$, Nik1p, Chk1p) and the response regulator Ssk1p (Li et al., 2004; Roman et al., 2005; Cheetham et al., 2007) the molecular background of osmotic stress signalling has remained yet to be elucidated (Cheetham et al., 2007). Sho1p-Ste11p signalling regulates cell wall biogenesis and morphogenesis via Cek1p MAPK pathway in this fungus (Román et al., 2005; Monge et al., 2006). Ssk2p-Pbs2p-Hog1p-type MAPK pathway is also present in another human pathogen, Cryptococcus neoformans (Bahn et al., 2007).

Osmotic and oxidative stress signalling in A. nidulans - similarity and differences with yeast stress signalling and response systems. Similar to the stress-responsive Sty1 - Hog1p MAPK pathways of $S$. pombe and $C$. albicans, the SskB - PbsB - HogA (syn. SakA) MAPK pathway of A. nidulans (Figure 1, Table 2) transmits osmotic (Han and Prade, 2002; Kawasaki et al., 2002; Furukawa et al., 2005; Hagiwara et al., 2007a; Vargas-Pérez et al., 
2007) and oxidative (Kawasaki et al., 2002; Furukawa et al., 2005; Hagiwara et al., 2007a) stress signals and is activated by the response regulator SskA (Hagiwara et al., 2007a). It is worth noting that the $\Delta s s k A$ mutants of Vargas-Pérez et al. (2007) resisted $\mathrm{H}_{2} \mathrm{O}_{2}$ up to $2 \mathrm{mM}$ and were capable of growing even in the presence of $4 \mathrm{mM} \mathrm{H}_{2} \mathrm{O}_{2}$ but reduced induction of a catB:lacZ reporter gene fusion in $\triangle s a k A$ background was observed by the same authors. On the contrary, the $\Delta s s k A$ mutant of Hagiwara et al. (2007a) possessed a hypersensitive phenotype to oxidative stress particularly to that caused by $\mathrm{H}_{2} \mathrm{O}_{2}$. These observations together with the transient phosphorylation of SakA under both osmotic and oxidative stress strengthen the view that the SskA - SakA (syn. HogA) system transduces different types of stress signals (Kawasaki et al., 2002; Furukawa et al., 2005). Importantly, sakA complemented $\Delta s p c 1$ (syn. styl) defects in $S$. pombe and the gene product was phosphorylated in response to both osmotic and oxidative stress in fission yeast (Kawasaki et al., 2002).

Other likely upstream components of stress signalling via SskA-dependent His-to-Asp phoshorelay system are YpdA phosphotransfer protein (Furukawa et al., 2005; Vargas-Perez et al., 2007) and NikA, a Mak2-type histidine kinase, which transmits fungicide signals but does not seem to be indispensable in either oxidative or osmotic stress responses (Hagiwara et al., 2007b; Vargas-Pérez et al., 2007) (Figure 1, Table 2). Interestingly, the homology between $S$. cerevisiae Ypd1p and A. nidulans YpdA is moderate with an $E$-value of 5E-18 (Table 3) but $y p d A$ complemented $\triangle Y P D 1$ mutation in S. cerevisiae (Furukawa et al., 2005).

Another candidate to trigger osmotic stress signals in A. nidulans is the TcsB histidine kinase, an orthologue of yeast $\operatorname{Sin} 1$ p (Catlett et al., 2003; Table 2), which complements $\Delta \sin 1$ defect in $S$. cerevisiae (Furukawa et al., 2002). Although the $\Delta t c s B$ gene deletion mutant did not exhibit any osmosensitive phenotype (Furukawa et al., 2002) the A. nidulans TcsB - YpdA SskA two-component system may possess a physiological function similar to that of the yeast Sln1p-Ypd1p-Ssk1p proteins (Furukawa et al., 2005). Unlike in yeasts and similar to filamentous fungus pathogens (Catlett et al., 2003), the A. nidulans genome contains as many as 15 genes coding for histidine kinases (Vargas-Pérez et al., 2007; Suzuki et al., 2008), and this considerable redundancy may explain the absence of any clear-cut phenotype in the $\Delta t c s B$ mutant. Interestingly, another non-essential sensor kinase, TcsA, may be required to produce conidia under different kinds of oxidative stress (Appleyard et al., 2000) but TcsA - YpdA response regulator signalling pathway has not been demonstrated. Other A. nidulans histidine 
kinases with considerable homologies to $S$. pombe Mak1 and Mak2 are the putative gene products of AN3101.3 and AN3102.3 ORFs, respectively (Table 2).

The A. nidulans SskB - PbsB - HogA/SakA MAPK pathway is activated only by twocomponent signalling because PbsB lacks a typical Pro-rich motif, which is required for binding Pbs2p to Sho1p in budding yeast (Zarrinpar et al., 2003; Furukawa et al., 2005). Considering that the Pro-rich Sho1p-binding domain is also absent in C. albicans Pbs2p MAPKK it is reasonable to assume that the primary role of Sholp-signalling is not in osmosensing but in morphogenesis (Krantz et al., 2006a). In good accordance with this, other A. nidulans proteins with similarity to elements of the yeast Sholp branch play important roles in hyphal morphogenesis (ModA, a Cdc42p-like protein; Virag et al., 2007) or sexual development (SteC, a Ste11p-like protein; Wei et al., 2003). It is noteworthy that the homologies between yeast Sho1p, Msb2p, Ste50p (important elements of Sho1p-dependnet stress signalling) and their counterparts in A. nidulans were characterized with $E$-values around or above the $E \leq 1 \mathrm{E}-40$ cut-off (6E-17 - 9E-37, Table 3, and 1E-32 - 8E-42 for putative Sho1p orthologues in the aspergilli).

Another spectacular difference between Hog 1p-dependent and HogA/SakA-dependent stress response regulatory pathways is that PbsB MAPKK activates another Hog1p orthologue, $\mathrm{MpkC}$, in A. nidulans, which is absent in yeasts, and the overexpression of which suppresses the high-osmolarity sensitivity of $\Delta h o g A$ (Furukawa et al., 2005). On the other hand, MpkC is dispensable in osmoadaptation (Furukawa et al., 2005).

An orthologue of Prr1 (S. pombe) and $\operatorname{Skn7p}$ (S. cerevisiae) response regulators, SrrA, also functions in A. nidulans (Hagiwara et al., 2007a; Vargas-Pérez et al., 2007) (Figure 1, Table 2). SrrA is required for oxidative stress (especially against $\mathrm{H}_{2} \mathrm{O}_{2}$ and $t \mathrm{BOOH}$ ) and, slightly, for osmotic stress resistances (Hagiwara et al., 2007a; Vargas-Pérez et al., 2007).

No information is available at the moment on the nuclear import and export of phosphorylated HogA/SakA MAPK and YpdA histidine-containing phosphotransmitter although putative orthologues of Gsp1p-Nmd5p importin and Crm1p export factor can be found (Table 2). Moreover, an exportin candidate, KapK, has been shown to take part in the nuclear export of NirA nitrate assimilation transcription factor (Bernreiter et al., 2007). Similarly, little is known about the dephosphorylation of HogA/SakA but osmotic stress dependent up- 
regulation of the putative protein phosphatase gene $p t p A$ has been reported (Han and Prade, 2002).

Among the potential substrates of $\operatorname{Hog} \mathrm{A} / \mathrm{SakA}$, RpdA and AtfA (E-value for homology between S. pombe Atf1 and A. nidulans AtfA is 1E-36, Table 3) have been reported or hypothesized (Graessle et al., 2000; Aguirre et al., 2005). The A. nidulans RcoA shares sequence similarity with $S$. cerevisiae Tup1 and $N$. crassa RCO1 (Hicks et al., 2001), and it is another possible interacting partner of HogA/SakA. RcoA has pleitropic effects on vegetative growth, sexual and asexual spore production and sterigmatocystin biosynthesis but does not regulate carbon catabolite repression in A. nidulans (Hicks et al., 2001; Todd et al., 2006). One explanation for the reduced metabolic regulatory activity of RcoA may be the absence of Cyc8p(Ssn6p) and Sko1p co-repressor orthologues in the A. nidulans genome (Tables 1 and 2), which prevents the formation of repressor complexes similar to Tup1p-Cyc8p(Ssn6p)Sko1p in budding yeast (Proft et al., 2001). Interestingly, other aspergilli harbour Cyc8p orthologues in their genomes (Table 2).

In budding yeast, Sko1p is the orthologue of $S$. pombe's Atf1 'general stress' transcription factor (Gasch, 2007) but the activation of Skolp bZip protein is only dependent on osmotic stress in $S$. cerevisiae, which role is quite minute in comparison to the cardinal role Msn2p/Msn4p C2H2 zinc finger proteins play in the regulation of ESR (Gasch et al., 2000; Gasch, 2007). The closest homologues of Skolp are also AtfAs in the genomes of the aspergilli (Table 3) but these homologies are low. Therefore, further research is needed to answer the important question whether or not AtfAs are orthologues of Sko1p and will take over only the osmotic stress regulatory functions clearly attributed to Sko1p in S. cerevisiae. Or, alternatively, AtfAs are orthologues of fission yeast's Atf1 and occupy a central position in the coordination of ESR including oxidative stress (Aguirre et al., 2005).

Importantly, a Msn2p/Msn4p-type protein, MsnA ( $E$-values for homology with budding yeast's Msn2p and Msn4p are 1E-16 and 2E-17, respectively; Table 3), was also annotated in A. nidulans, which was induced by versatile types of stress (Han and Prade, 2002). This opens the possibility of a complex co-regulation of stress response genes by Atf1-type bZip and Msn2p/Msn4p-type $\mathrm{C} 2 \mathrm{H} 2$ zinc finger transcriptional factors in A. nidulans. A putative orthologue of A. nidulans MsnA has been characterized in Trichoderma atroviride, which is called Seb1 ('stress response element binding protein'; $E$-value for homology between $A$. 
nidulans MsnA and T. atroviride Seb1 is 5E-55) and is involved in but not essential for osmotic stress defence (Peterbauer et al., 2002; Seidl et al., 2004). The expression of $T$. atroviride sebl did not respond to cadmium, $\mathrm{pH}$ and membrane perturbance stress, and overexpressed seb1 cDNA did not complement a S. cerevisiae MSN2/MSN4 deletion mutant (Peterbauer et al., 2002).

A series of stress-responsive genes normally subjected to Hog1p-Skolp-dependent regulation under osmotic stress is controlled by the Yap1p transcription factor (a Hog1p-independent regulator) when budding yeast is exposed to oxidative stress (Gasch et al., 2000; Rep et al., 2001). By analogy, the bZip-type products of A. nidulans AN7513.3, called NapA (Asano et al., 2007), and A. fumigatus Afu6g09930, called AfYap1 (Lessing et al., 2007), also govern the expression of an array of oxidative stress responsive genes but the $E$-values between yeast Yap1p and the A. nidulans or A. fumigatus NapA and AfYap1 are 5E-13 and 4E-13, respectively, indicating relatively low homologies (Table 3). On the other hand, highhomology NapA (AfYap1) orthologues (expectation values 0.0) can be identified in all Aspergillus genomes screened.

Intriguingly, no Hot $1 p$ transcription factor (Alepuz et al., 2003) orthologue was found in the genomes of A. nidulans and other aspergilli (Table 3, Supplementary Tables 1-8). The lack of a Hot1p orthologue in A. nidulans may explain that $g f d A$, which is homologous to the yeast Hot1p-target Gpd1p (Rep et al., 2000), is not responsive to osmotic and oxidative stress (Han and Prade, 2002). The aspergilli's genomes do not accommodate any orthologues of Msn1p stress-response transcriptional activator (Rep et al., 1999) either (Table 3). Some other fungi responding to stress without the involvement of any Hot1p and Msn1p orthologues have been reported by Krantz et al. (2006a) and include S. pombe, Yarrowia lipolytica, N. crassa and Ustilago maydis.

The list of the potential target genes of HogA/SakA and/or SrrA-dependent regulations in $A$. nidulans includes the GPD2 (S. cerevisiae) orthologue gfdB (Han and Prade, 2002; Furukawa et al., 2007), enaA (Han and Prade, 2002), catB (Hagiwara et al., 2007a; Vargas-Pérez et al., 2007) as well as thiO/trxA and $\operatorname{trxB} / \operatorname{trxR}$ (Asano et al., 2007; Thön et al., 2007) (Table 2).

SskA response regulator is also implicated in stress-tolerant conidia formation because many trehalose and glycerol metabolic genes ( $g f d A$ and $g f d B$, glycerol-3-phosphate dehydrogenases; 
gldB, glycerol dehydrogenase; tpsA, trehalose-6-phosphate synthase; orlA, trehalose-6phosphate phosphatase; treB, neutral trehalase; Borgia et al., 1996; d'Enfert et al., 1999; Fillinger et al., 2001a, 2001b, Han and Prade, 2002; de Vries et al., 2003) are down-regulated in conidia of the $\triangle s s k A$ mutant in addition to catA general stress tolerance catalase gene (Figure 1; Hagiwara et al., 2007a; Vargas-Pérez et al., 2007).

Osmotic and oxidative stress response in other aspergilli. Stress signalling and regulatory pathways are very similar in all aspergilli studied (Table 2; Supplementary Tables 1-8). A. fumigatus SakA MAPK plays a pivotal role in oxidative stress response of this opportunistic human pathogen meanwhile TcsB histidine kinase is dispensable (Du et al., 2006). MpkC MAPK signalling is important in carbon source utilization but not in high-osmolarity medium (Reyes et al., 2006). Considering Prr1/Skn7p-type response regulators, the SKN7 orthologue of A. fumigatus, afskn7, was identified and $\Delta a f s k n 7$ showed a growth inhibition phenotype in the presence of $\mathrm{H}_{2} \mathrm{O}_{2}$ and tert-butylhydroperoxide (Lamarre et al., 2007). According to Sakamoto et al. (2008), the oxidative stress resistance gene catA is under AtfB bZip transcription factor (locus ID: AO090120000418) control in A. oryzae conidia, and A. oryzae genome also harbours an AtfA orthologue (Tables 2 and 3). Interestingly, A. nidulans and A. terreus do not have any AtfB orthologue obeying the $\mathrm{E} \leq 1 \mathrm{E}-40$ cut-off criteria but putative AtfB proteins encoded by the loci A. nidulans AN8643.3 and A. terreus ATEG_01978 were found with $E$-values $2 \mathrm{E}-20$ and $9 \mathrm{E}-25$, respectively. In other aspergilli, high-homology (E value < 1E-40) AtfB orthologues were annotated, encoded by the loci A. flavus AFL2G_08419 (3E-162), N. fischeri NFIA_074120 (2E-71), A. fumigatus Afu5g12960 (4E77), A. clavatus ACLA_015960 (9E-79) and A. niger fge1_pg_C_8000498 (9E-56).

It is intriguing that there are two orthologues of the yeast Ssk1p (A. nidulans orthologue SskA) response regulator in the genome of A. flavus (ORFs AFL2G_06337 and AFL2G_12585, Table 2; E-values 4E-45 and 5E-20, respectively), and Rpd3p (A. nidulans orthologue RpdA) histone deacetylase also has two orthologues in this fungus (ORFs AFL2G_08263 and AFL2G_03062; E-values 2E-174 and 4E-139, respectively). Hence, this important aflatoxin-producer and opportunistic human pathogen seems to possess a more complex osmotic and oxidative stress defence system than other aspergilli. 
The important citric acid, gluconic acid and hydrolyse producer fungus A. niger lacks the Sln1p-type (TcsB-type) histidine kinase heavily supporting the view that TcsB is dispensable in the aspergilli (Furukawa et al., 2002; Du et al., 2006). The lack of transmembrane-spanning histidine kinase is not unprecedented among fungi; the smut fungus $U$. maydis does not possess any apparent Sln1p orthologue similar to fission yeast (Krantz et al., 2006a,b).

\section{Other types of stress}

Thermal stress and Unfolded Protein Response (UPR). Although Hog1p/Sty1-type MAPKs are activated by heat stress as well in S. pombe (Degols et al., 1996; Samejima et al., 1997) and N. crassa (Noguchi et al., 2007) A. nidulans HogA/SakA does not seem to respond to thermal stress in vegetative tissue (Han and Prade, 2002; Kawasaki et al., 2002) but it is required for general stress tolerance, including heat stress, of germinated conidia (Kawasaki et al., 2002).

As far as the response regulator Skn7p is concerned, it interacts with the heat shock factor Hsf1p in S. cerevisiae to activate heat shock proteins under oxidative stress (Raitt et al., 2000). In the aspergilli, no orthologue of Hsf1p obeying the $E \leq 1 \mathrm{E}-40$ cut-off rule was identified although putative HsfA proteins with 3E-23 - 2E-26 $E$-values were found (ORF IDs: A. nidulans: AN8035; A. clavatus: ACLA_003360; A. flavus: AFL2G_01739; A. fumigatus: Afu5g01900; A. niger: est_fge1_pg_C_7042; A. oryzae: A0090003001329; A. terreus: ATEG_09811; N. fischeri: NFIA_040210). Furthermore, no heat sensitive phenotype of $\Delta a f s k n 7$ was described in A. fumigatus (Lamarre et al., 2007).

In budding yeast, a large group of oxidative stress and heat shock responsive genes are regulated by Msn2p/Msn4p 'general stress' transcriptional factors (Gasch et al., 2000, Causton et al., 2001), and the expression of $A$. nidulans $m s n A$ was also reported to respond to heat by Han and Prade (2002). The participation of MsnA in the regulation of heat response genes is therefore foreseeable but needs verification.

Elements of RAS/Cyr1p (adenylate cyclase)/cAMP-dependent protein kinase A (RAS/cAMP/PKA) signalling and regulatory pathway (Estruch, 2000) have been annotated in the genomes of all aspergilli studied (Supplementary Tables 1-8) including orthologues of yeast Ras1p (Estruch, 2000), N. crassa CR-1 adenylate cyclase (Cruz et al., 1988) and yeast 
Bcy1p cAMP-dependent protein kinase A regulatory subunit (Toda et al., 1987). RAS/cAMP/PKA signalling influences negatively the induction of Msn2p/Msn4p regulon by thermal stress and, hence, its reduced activity correlates well with developing thermotolerance in stress-exposed yeast cells (Görner et al., 1998; Garreau et al., 2000; Longo 2003). Both the catalytic (PkaC) and regulatory (PkaR) subunits of PKA of A. niger has been cloned and characterized (Benčina et al., 1997; Saudohar et al., 2002), and heat shock decreased markedly pkaC mRNA levels in this fungus (Benčina and Legiša, 2000).

As summarized in Supplementary Tables 1-8, aspergilli genomes also harbour putative orthologues of known cell integrity MAPKs (Mkc1p, C. albicans; Navarro-Garcia et al., 1995; S1t2p, S. cerevisiae; Hahn and Thiele, 2002), type 1 protein phosphatase (PP1C; Glc7p, S. cerevisiae; Tung et al., 1995), type 2C protein phosphatase (PP2C; Ptc1, Ptc2; S. pombe; Shiozaki and Russel, 1995), nucleoside diphosphate kinase (NDK-1; N. crassa; Yoshida et al., 2006) and calcineurin (CnaA; A. oryzae; Juvvadi et al., 2003) with predictably important roles in the heat shock response of this genus.

Targets of heat shock response regulators may include trehalose metabolic enzymes (TreB, $A$. nidulans, d'Enfert et al., 1999; TpsA and TpsB, A. niger, Wolschek and Kubicek, 1997; TpsA, A. nidulans, Fillinger et al., 2001) and catalases (CatA, A. nidulans, Noventa-Jordão et al., 1999; CatB, A. nidulans, Kawasaki et al., 1997; CatB, A. oryzae, Hisada et al., 2008). As has been shown most recently, the expression of conidia-specific catA is subjected to AtfBdependent regulation in A. oryzae (Sakamoto et al., 2008).

Heat shock proteins play versatile roles to prevent the accumulation of denatured and aggregated proteins in stress-exposed cells (Riezman, 2004). In the aspergilli, putative orthologues of $N$. crassa HSP60 (Ostermann et al., 1989), HSP70 (Kapoor et al., 1995), HSP80 (Roychowdhury et al., 1992), C. albicans Hsp70p (La Valle et al., 1995), Hsp90p (Swoboda et al., 1995) and S. cerevisiae Hsp104p (Seppä et al., 2004) were annotated (Supplementary Tables 1-8). Misfolded mitochondrial proteins are likely degraded by the orthologue of the Pim1p protease (Wagner et al., 1994), and the removal of misfolded and denatured proteins is ubiquitinylation-dependent in the aspergilli under different stress conditions (Noventa-Jordão et al., 2000). 
Among the annotated Unfolded Protein Response (UPR) proteins, all Aspergillus genomes contained orthologues of the yeast Ire1p and Kar2p proteins obeying the $E \leq 1 \mathrm{E}-40$ cut-off criteria (Supplementary Tables 1-8). Any impairment of secretory and membrane protein folding in the ER, caused e.g. by heat shock, disulphide bond reducing agents, inhibitors of protein glycosylation, triggers UPR, which is initiated by the Ire1p (ER-stress sensor) - BiP (Kar2p; a Hsp70p-type Ire1p-modulator) system (Bertolotti et al., 2000; Kimata et al., 2007). The transmembrane protein Ire1p is a bifunctional enzyme (Ser/Thr kinase endoribonuclease), the lumenal domain of which interacts with Kar2p molecular chaperone. Upon ER-stress, Kar2p binds unfolded protein and leaves Ire1p (Okamura et al., 2000), which undergoes aggregation and directly associates with unfolded proteins leading to its activation (Credle et al., 2005; Kimata et al., 2007). Activated Ire1p catalyses the splicing of HAC1 premRNA allowing the synthesis of Hac1p, a bZip-type transcription factor, which is a major regulator of UPR in budding yeast (Mori et al., 1996; Sidrauski and Walter, 1997; Kimata et al., 2006). Putative Hac1p orthologues were also identified in all Aspergillus genomes studied but the homology between yeast and Aspergillus proteins was quite low (E-value 1E-12 - 6E$13)$.

Other annotated UPR proteins in the aspergilli are homologues of Lhs1p (S. cerevisiae; Mori et al., 1998) and calnexin (S. pombe; Cnx1; Parlati et al., 1995) molecular chaperons and Scj1p, a homologue of bacterial DnaJ, cooperating with Kar2p in yeast (Silberstein et al., 1998). The Ire1p sensor autophosphorylates itself under UPR (Kimata et al., 2007) and is dephosphorylated by Dcr2p phosphatase antagonizing UPR signalling (Guo and Polymenis, 2006). A. nidulans cyclophilin B (CypB) may also be an important factor in proper protein folding in ER under thermal stress (Joseph et al., 1999). Considering other subcellular structures, protein CgrA contributes to the protection of nucleolar integrity under heat stress in A. fumigatus (Bhabhra et al., 2006).

Enzyme production by recombinant aspergilli is of primary industrial importance considering the production of both native and heterologous proteins (Archer 1994; Davies 1994; Gouka et al., 1997; Archer and Peberdy, 1997; Guillemette et al., 2007). Because accumulation of misfolded heterologous proteins in the ER initiates UPR and, therefore, slows down protein secretion ('secretion stress') several elements and regulation of UPR are well-characterized even functionally in the aspergilli (Guillemette et al., 2007). For example, HacA transcription factors (Hac1p orthologues) have been cloned and characterized in A. niger (Al-Sheikh et al., 
2004; Mulder et al., 2004, 2006; Davé et al., 2006; Guillemette et al., 2007), A. awamori (Valkonen et al., 2003) and A. oryzae (Nakajima et al., 2006). Other described UPR elements in the aspergilli are BipA chaperones, (Kar2p orthologues; A. niger: van Gemeren et al., 1997; Punt et al., 1998; Al-Sheikh et al., 2004; Davé et al., 2006; A. awamori: van Gemeren et al., 1997, 1998; Punt et al., 1998; Lombraña et al., 2004; A. oryzae: Kasuya et al., 1999), protein disulphide isomerases (PdiA, A. niger: Ngiam et al., 2000; Al-Sheikh et al., 2004; PrpA, A. awamori: Wang and Ward, 2000; PdiA, A. awamori: Moralejo et al., 2001) and calnexin chaperone (ClxA, A. niger: Conesa et al., 2002).

Starvation. Nitrogen starvation causes G1-arrest in mitosis in fission yeast (Kumada et al., 1995) and triggers sexual differentiation (Nadin-Davis and Nasim, 1990; Sato et al., 1994; Peng et al., 2003). Several homologues of elements of fission yeast's sexual differentiation signalling and regulation can be found in the aspergilli as summarized in Supplementary Tables 1-8. Nutrient starvation also influences the asexual sporulation of A. nidulans via induction of BrlA, a sporulation-specific transcriptional regulator (Skromne et al., 1995). Regulatory elements of nutrient deprivation stress response may include HogA/SakA MAPK (Xue et al., 2004), putative orthologues of $N$. crassa RCO1 (Lee and Ebbole, 1998; orthologues in the aspergilli are RcoA proteins), S. cerevisiae Snf1p protein kinase (Kuchin et al., 2002) and Dpl1p sphingosine-1-phosphate lyase (Gottlieb et al., 1999). Target genes include homologues of yeast MEP2 ammonium permease (Biswas and Morschhäuser, 2005), ASP3 asparaginase (Bon et al., 1997), YCSB (PRB1; Teichert et al., 1989) and isp6 (Nakashima et al., 2006) vacuolar proteases, GGT1 $\gamma$-glutamyltranspeptidase I (Kim et al., 2005), and A. nidulans alcohol dehydrogenase II (ADHII; Jones et al., 2001). Phosphorstarvation seems to induce nucleotide phosphatases like Npplp (Kennedy et al., 2005).

Other stress. Genes encoding glutathione S-transferases (Fraser et al., 2002; Burns et al., 2005) are present in the genomes of the aspergilli, and A. fumigatus GstA, GstB and GstC also possess glutathione peroxidase activity (Burns et al., 2005). Glutathione S-transferases play pivotal roles in oxidative stress defence and the detoxification of xenobiotics and heavy metals (Fraser et al., 2002; Pócsi et al., 2004; Burns et al., 2005).

The aspergilli also have orthologues of the yeast flavohemoglobin Yhb1p (Supplementary Tables 1-8), which is the centrepiece of nitrosative stress defence in both $S$. cerevisiae (Liu et 
al., 2000; Horan et al., 2006) and the opportunistic pathogen C. albicans (Ullmann et al., 2004; Hromatka et al., 2005).

DNA repair. Elements of DNA repair systems were more recently annotated and discussed in details in A. nidulans by Goldman and Kafer (2004). Although a detailed description of DNA repair systems in aspergilli was beyond the scope of this paper gene annotations were completed and DNA repair data are summarized in Supplementary Tables 1-8. Transcriptome analyses of $A$. nidulans exposed to camptothecin (a topoisomerase I inhibitor) and A. nidulans atmA (an orthologue of human ATM, encoding a phosphatidyl-3-kinase-related protein kinase, a central regulator of DNA damage response) null mutant are also available in the literature demonstrating the complexity of DNA damage responses and the multiple pathways mediating DNA repair in the aspergilli (Malavazi et al., 2006, 2007).

ESR in the aspergilli. Unfortunately, whole-genome analyses of general stress responses have remained yet to be performed in the aspergilli (Gasch, 2007). Although many elements of stress sensing, signalling and response typical of yeasts are present in the Aspergillus genomes and, hence, ESR-like responses are foreseeable, still little is known about the organisation and hierarchy of these elements. As a result of previous observations and this annotation study, proteins of SskA - HogA/SakA stress signalling and regulation pathways are present and may be cardinal in the regulation of different types of stress responses (e.g. responses to osmotic, oxidative, starvation and even heat stress in germinating conidia) in all aspergilli and, in this regard, these euascomycetes are closer to the fission yeast $S$. pombe than to the budding yeast S. cerevisiae (Gasch, 2007). This view is further strengthened by the observation that the $S$. cerevisiae Sholp-type stress signalling does not function in $A$. nidulans, and this transmembrane sensor kinase in the upstream branch of Hog1p MAPK pathway is absent in fission yeast. This means that Sty1/HogA MAPK pathway is activated only by two-component signalling in both fission yeast and the aspergilli.

The abundance of annotated histidine kinases, MAPKs (HogA/SakA, MpkC), response regulators (two SskAs in A. flavus) and transcriptional regulators, e.g. AtfA, AtfB, NapA (AfYap1), MsnA (no orthologue in fission yeast!), RpdA (two orthologues in A. flavus), may be indicative of a complex and robust stress defence system controlled by a high-complexity regulatory network in these filamentous fungi. The absence of orthologues of important transcriptional regulators like Sko1p, Hot1p and Msn1p in the aspergilli and Cyc8p in A. 
nidulans together with the relatively low $(E>1 \mathrm{E}-40)$ homologies between yeast and Aspergillus Ypd1p - YpdA, Msn2p/Msn4p - MsnA, Atf1 - AtfA, Yap1p - NapA (AfYap1), Hsf1p - HsfA and Hac1p - HacA proteins challenges the view that yeast stress response systems can easily be reconstructed in silico in the aspergilli. Hence, these findings shed light on the limits of yeast-based models in filamentous fungus genome annotations.

\section{Acknowledgements}

This work was supported financially by the Hungarian National Office for Research and Technology (grant reference number OMFB 01501/2006) and by the GENOMNANOTECHDEBRET (RET-06/2004).

\section{References}

Aguirre, J., Ríos-Momberg, M., Hewitt, D., Hansberg, W., 2005. Reactive oxygen species and development in microbial eukaryotes. Trends Microbiol. 13, 111-118.

Akhtar, N., Påhlman, A.K., Larsson, K., Corbett, A.H., Adler, L., 2000. SGD1 encodes an essential nuclear protein of Saccharomyces cerevisiae that affects expression of the GPD1 gene for glycerol 3-phosphate dehydrogenase. FEBS Lett. 483, 87-92.

Alepuz, P.M., Jovanovic, A., Reiser, V., Ammerer, G., 2001. Stress-induced map kinaseHog1 is part of transcription activation complexes. Mol. Cell. 7, 767-777.

Alepuz, P.M., de Nadal, E., Zapater, M., Ammerer, G., Posas, F., 2003. Osmostress-induced transcription by Hot1 depends on a Hog1-mediated recruitment of RNA Pol II. EMBO J. $22,2433-2442$.

Al-Sheikh, H., Watson, A.J., Lacey, G.A., Punt, P.J., MacKenzie, D.A., Jeenes, D.J., Pakula, T., Penttilä, M., Alcocer, M.J., Archer, D.B., 2004. Endoplasmic reticulum stress leads to the selective transcriptional downregulation of the glucoamylase gene in Aspergillus niger. Mol. Microbiol. 53, 1731-1742.

Altschul, S.F., Madden, T.L., Schäffer, A.A., Zhang, J., Zhang, Z., Miller, W., Lipman, D.J., 1997. Gapped BLAST and PSI-BLAST: a new generation of protein database search programs. Nucleic Acids Res. 25, 3389-3402. 
Ansell, R., Granath, K., Hohmannn, S., Thevelein, J.M., Adler, L., 1997. The two isoenzymes for yeast $\mathrm{NAD}^{+}$-dependent glycerol 3-phosphate dehydrogenase encoded by GPD1 and GPD2 have distinct roles in osmoadaptation and redox regulation. EMBO J. 16, 21792187.

Appleyard, M.V.C.L., McPheat, W.L., Stark, M.J.R., 2000. A novel 'two-component' protein containing histidine kinase and response regulator domains required for sporulation in Aspergillus nidulans. Curr. Genet. 37, 364-372.

Arana, D.M., Nombela, C., Alonso-Monge, R., Pla, J., 2005. The Pbs2 MAP kinase kinase is essential for the oxidative stress response in the fungal pathogen Candida albicans. Microbiology 151, 1033-1049.

Archer, D.B., 1994. Enzyme production by recombinant Aspergillus. Bioprocess Technol. 19, 373-393.

Archer, D.B., Peberdy, J.F., 1997. The molecular biology of secreted enzyme production by fungi. Crit. Rev. Biotechnol. 17, 273-306.

Arnaud, M.B., Costanzo, M.C., Skrzypek, M.S., Binkley, G., Lane, C., Miyasato, S.R., Sherlock, G.., 2005. The Candida Genome Database (CGD), a community resource for Candida albicans gene and protein information. Nucleic Acids Res. 33, D358-D363.

Asano, Y., Hagiwara, D., Yamashino, T., Mizuno, T., 2007. Characterization of the bZip-type transcription factor NapA with reference to oxidative stress response in Aspergillus nidulans. Biosci. Biotechnol. Biochem. 71, 1800-1803.

Ashburner, M., Ball, C.A., Blake, J.A., Botstein, D., Butler, H., Cherry, J.M., Davis, A.P., Dolinski, K., Dwight, S.S., Eppig, J.T., Harris, M.A., Hill, D.P., Issel-Tarver, L., Kasarskis, A., Lewis, S., Matese, J.C., Richardson, J.E., Ringwald, M., Rubin, G.M., Sherlock, G., 2000. Gene ontology: tool for the unification of biology. The Gene Ontology Consortium. Nature Genet. 25, 25-29.

Aslett, M., Wood, V., 2006. Gene Ontology annotation status of the fission yeast genome: preliminary coverage approaches 100\%. Yeast 13, 913-919.

Ayoubi, P., Jin, X., Leite, S., Liu, X., Marajaja, J., Abdurahman, A., Wan, Q., Yan, W., Misawa, E., Prade, R.A., 2002. PipeOnline 2.0: automated EST processing and functional data sorting. Nucleic Acids Res. 30, 4761-4769.

Bahn, Y.S., Geunes-Boyer, S., Heitman, J., 2007. Ssk2 mitogen-activated protein kinase kinase kinase governs divergent patterns of the stress-activated Hog1 signaling pathway in Cryptococcus neoformans. Eukaryot. Cell 6, 2278-2289. 
Benčina, M., Panneman, H., Ruijter, G.J., Legiša, M., Visser, J., 1997. Characterization and overexpression of the Aspergillus niger gene encoding the cAMP-dependent protein kinase catalytic subunit. Microbiology 143, 1211-1220.

Benčina, M., Legiša, M., 2000. Stress mediated changes in expression of the $p k a C$ gene, encoding the catalytic subunit of cAMP-dependent protein kinase, in Aspergillus niger. Pflügers Arch. 439, R76-R78.

Bernreiter, A., Ramon, A., Fernández-Martínez, J., Berger, H., Araújo-Bazan, L., Espeso, E.A., Pachlinger, R., Gallmetzer, A., Anderl, I., Scazzocchio, C., Strauss, J., 2007. Nuclear export of the transcription factor NirA is a regulatory checkpoint for nitrate induction in Aspergillus nidulans. Mol. Cell. Biol. 27, 791-802.

Bertolotti, A., Zhang, Y., Hendershot, L.M., Harding, H.P., Ron, D., 2000. Dynamic interaction of BiP and ER stress transducers in the unfolded-protein response. Nat. Cell Biol. 2, 326-332.

Bhabhra, R., Zhao, W., Rhodes, J.C., Askew, D.S., 2006. Nucleolar localization of Aspergillus fumigatus CgrA is temperature-dependent. Fungal Genet. Biol. 43, 1-7.

Bilsland-Marchesan, E., Ariño, J., Saito, H., Sunnerhagen, P., Posas, F., 2000. Rck2 kinase is a substrate for the osmotic stress-activated mitogen-activated protein kinase Hog1. Mol. Cell. Biol. 20, 3887-3895.

Biswas, K., Morschhäuser, J., 2005. The Mep2p ammonium permease controls nitrogeninduced filamentous growth in Candida albicans. Mol. Microbiol. 56, 649-669.

Bon, E.P., Carvajal, E., Stanbrough, M., Rowen, D., Magasanik, B., 1997. Asparaginase II of Saccharomyces cerevisiae. GLN3/URE2 regulation of a periplasmic enzyme. Appl. Biochem. Biotechnol. 63-65, 203-212.

Borgia, P.T., Miao, Y., Dodge, C.L., 1996. The orlA gene from Aspergillus nidulans encodes a trehalose-6-phosphate phosphatase necessary for normal growth and chitin synthesis at elevated temperatures. Mol. Microbiol. 20, 1287-1296.

Boy-Marcotte, E., Perrot, M., Bussereau, F., Boucherie, H., Jacquet, M., 1998. Msn2p and Msn4p control a large number of genes induced at the diauxic transition which are repressed by cyclic AMP in Saccharomyces cerevisiae. J. Bacteriol. 180, 1044-1052.

Buck, V., Quinn, J., Pino, T.S., Martin, H., Saldanha, J., Makino, K., Morgan, B.A., Millar, J.B.A., 2001. Peroxide sensors for the fission yeast stress-activated mitogen-activated protein kinase pathway. Mol. Biol. Cell 12, 407-419. 
Burns, C., Geraghty, R., Neville, C., Murphy, A., Kavanagh, K., Doyle, S., 2005. Identification, cloning, and functional expression of three glutathione transferase genes from Aspergillus fumigatus. Fungal Genet. Biol. 42, 319-327.

Catlett, N.L., Yoder, O.C., Turgeon, B.G., 2003. Whole-genome analysis of two-component signal transduction genes in fungal pathogens. Eukaryot. Cell 2, 1151-1161.

Chauhan, N., Inglis, D., Román, E., Pla, J., Li, D., Calera, J.A., Calderone, R., 2003. Candida albicans response regulator SSK1 regulates a subset of genes whose functions are associated with cell wall biosynthesis and adaptation to oxidative stress. Eukaryot. Cell 2, 1018-1024.

Chauhan, N., Latge, J.P., Calderone, R., 2006. Signalling and oxidant adaptation in Candida albicans and Aspergillus fumigatus. Nature Rev. Microbiol. 4, 435-444.

Causton, H.C., Ren, B., Koh, S.S., Harbison, C.T., Kanin, E., Jennings, E.G., Lee, T.I., True, H.L., Lander, E.S., Young, R.A., 2001. Remodelling of yeast genome expression in response to environmental changes. Mol. Biol. Cell 12, 323-337.

Cheetham, J., Smith, D.A., da Silva Dantas, A., Doris, K.S., Patterson, M.J., Bruce, C.R., Quinn, J., 2007. A single MAPKKK regulates the Hog1 MAPK pathway in the pathogenic fungus Candida albicans. Mol. Biol. Cell 18, 4603-4614.

Chen, D., Toone, W.M., Mata, J., Lyne, R., Burns, G., Kivinen, K., Brazma, A., Jones, N., Bähler, J., 2003. Global transcriptional responses of fission yeast to environmental stress. Mol. Biol. Cell 14, 214-229.

Cherry, J.M., Ball, C., Weng, S., Juvik, G., Schmidt, R., Adler, C., Dunn, B., Dwight, S., Riles, L., Mortimer, R.K., Botstein, D., 1997. Genetic and physical maps of Saccharomyces cerevisiae. Nature 387, 67-73.

Conesa, A., Jeenes, D., Archer, D.B., van den Hondel, C.A., Punt, P.J., 2002. Calnexin overexpression increases manganese peroxidase production in Aspergillus niger. Appl. Environ. Microbiol. 68, 846-851.

Credle, J.J., Finer-Moore, J.S., Papa, F.R., Stroud, R,M., Walter, P., 2005. On the mechanism of sensing infolded protein in the endoplasmic reticulum. Proc. Natl. Acad. Sci. USA 102, 18773-18784.

Cruz, A.K., Terenzi, H.F., Jorge, J.A., Terenzi, H.F., 1988. cyclic AMP-dependent, constitutive thermotolerance in the adenylate cyclase-deficient $c r-1$ (crisp) mutant of Neurospora crassa. Curr. Genet. 13, 451-454. 
Davé, A., Jeenes, D.J., Mackenzie, D.A., Archer, D.B., 2006. HacA-independent induction of chaperone-encoding gene bipA in Aspergillus niger strains overproducing membrane proteins. Appl. Environ. Microbiol. 72, 953-955.

Davies, R.W., 1994. Heterologous gene expression and protein secretion in Aspergillus. Prog. Ind. Microbiol. 29, 527-560.

Degols, G., Shiozaki, K., Russell, P. 1996. Activation and regulation of the Spc1 stressactivated protein kinase in Schizosaccharomyces pombe. Mol. Cell Biol. 16, 2870-2877.

de Nadal, E., Casadomé, L., Posas, F., 2003. Targeting the MEF2-like transcription factor Smp1 by the stress-activated Hog1 mitogen-activated protein kinase. Mol. Cell Biol. 23, 229-237.

de Nadal, E., Zapater, M., Alepuz, P.M., Sumoy, L., Mas, G., Posas, F., 2004. The MAPK Hog1 recruits Rpd3 histone deacetylase to activate osmoresponsive genes. Nature 427, 370-374.

d'Enfert, C., Bonini, B.M., Zapella, P.D., Fontaine, T., da Silva, A.M., Terenzi, H.F., 1999. Neutral trehalases catalyse intracellular trehalose breakdown in the filamentous fungi Aspergillus nidulans and Neurospora crassa. Mol. Microbiol. 32, 471-483.

de Vries, R.P., Flitter, S.J., van de Vondervoort, P.J., Chaveroche, M.K., Fontaine, T., Fillinger, S., Ruijter, G.J., d'Enfert, C., Visser, J., 2003. Glycerol dehydrogenase, encoded by gldB is essential for osmotolerance in Aspergillus nidulans. Mol. Microbiol. 49, 131141.

Du, C., Sarfati, J., Latge, J.P., Calderone, R., 2006. The role of the sakA (Hog1) and tcsB $(\sin 1)$ genes in the oxidant adaptation of Aspergillus fumigatus. Med. Mycol. 44, 211-218.

Dwight, S.S., Harris, M.A., Dolinski, K., Ball, C.A., Binkley, G., Christie, K.R., Fisk, D.G., Issel-Tarver, L., Schroeder, M., Sherlock, G., Sethuraman, A., Weng, S., Botstein, D., Cherry, J.M., 2002. Saccharomyces Genome Database (SGD) provides secondary gene annotation using the Gene Ontology (GO). Nucleic Acid Res. 30, 69-72.

Emri, T., Pócsi, I., Szentirmai, A., 1997. Glutathione metabolism and protection against oxidative stress caused by peroxides in Penicillium chrysogenum. Free Radic. Biol. Med. 23, 809-814.

Emri, T., Pócsi, I., Szentirmai, A., 1999. Analysis of the oxidative stress response of Penicillium chrysogenum to menadione. Free Radic. Res. 30, 125-132.

Enjalbert, B., Nantel, A., Whiteway, M., 2003. Stress-induced gene expression in Candida albicans: absence of a general stress response. Mol. Biol. Cell 14, 1460-1467. 
Estruch, F., 2000. Stress-controlled transcription factors, stress-induced genes and stress tolerance in budding yeast. FEMS Microbiol. Rev. 24, 469-486.

Fedorova, N.D., Badger, J.H., Robson, G.D., Wortman, J.R., Nierman, W.C., 2005. Comparative analysis of programmed cell death pathways in filamentous fungi. BMC Genomics 6, Article No. 177.

Fedorova, N.D., Khaldi, N., Joardar, V.S., Maiti, R., Amedeo, P., Anderson, M.J., Crabtree, J., Silva, J.C., Badger, J.H., Albarraq, A., Angiuoli, S., Bussey, H., Bowyer, P., Cotty, P.J., Dyer, P.S., Egan, A., Galens, K., Fraser-Liggett, C.M., Haas, B.J., Inman, J.M., Kent, R., Lemieux, S., Malavazi, I., Orvis, J., Roemer, T., Ronning, C.M., Sundaram, J.P., Sutton, G., Turner, G., Venter, J.C., White, O.R., Whitty, B.R., Youngman, P., Wolfe, K.H., Goldman, G.H., Wortman, J.R., Jiang, B., Denning, D.W., Nierman, W.C., 2008. Genomic islands in the pathogenic filamentous fungus Aspergillus fumigatus. PLoS Genet. 4, Article No. 1000046.

Fekete, A., Emri, T., Gyetvai, Á., Gazdag, Z., Pesti, M., Varga, Z., Balla, J., Cserháti, C., Emődy, L., Gergely, L., Pócsi, I., 2007. Development of oxidative stress tolerance resulted in reduced ability to undergo morphologic transitions and decreased pathogenicity in a $t$-butylhydroperoxide-tolerant mutant of Candida albicans. FEMS Yeast Res. 7, 834-847.

Ferrigno, P., Posas, F., Koepp, D., Saito, H., Silver, P.A., 1998. Regulated nucleo/cytoplasmic exchange of HOG1/MAPK requires the importin $\beta$ homologs NMD5/XPO1. EMBO J. 17, 5606-5614.

Fillinger, S., Ruijter, G., Tamás, M.J., Visser, J., Thevelein, J.M., d'Enfert, C., 2001a. Molecular and physiological characterization of the NAD-dependent glycerol 3-phosphate dehydrogenase in the filamentous fungus Aspergillus nidulans. Mol. Microbiol. 39, 145157.

Fillinger, S., Chaveroche, M.K., van Dijck, P., de Vries, R., Ruijter, G., Thevelein, J., d'Enfert, C., 2001. Trehalose is required for the acquisition of tolerance to a variety of stresses in the filamentous fungus Aspergillus nidulans. Microbiology 147, 1851-1862.

Fraser, J.A., Davis, M.A., Hynes, M.J., 2002. A gene from Aspergillus nidulans with similarity to URE2 of Saccharomyces cerevisiae encodes a glutathione S-transferase which contributes to heavy metal and xenobiotic resistance. Appl. Environ. Microbiol. 68, 2802-2808.

Furukawa, K., Katsumo, Y., Urao, T., Yabe, T., Yamada-Okabe, T., Yamada-Okabe, H., Yamagata, Y., Abe, K., Nakajima, T., 2002. Isolation and functional analysis of a gene, 
tcs $B$, encoding a transmembrane hybrid-type histidine kinase from Aspergillus nidulans. Appl. Environ. Microbiol. 68, 5304-5310.

Furukawa, K., Hoshi, Y., Maeda, T., Nakajima, T., Abe, K., 2005. Aspergillus nidulans HOG pathway is activated only by two-component signalling pathway in response to osmotic stress. Mol. Microbiol. 56, 1246-1261.

Furukawa, K., Yoshimi, A., Furukawa, T., Hoshi, Y., Hagiwara, D., Sato, N., Fujioka, T., Mizutani, O., Mizuno, T., Kobayashi, T., Abe, K., 2007. Novel reporter gene expression systems for monitoring activation of the Aspergillus nidulans HOG pathway. Biosci. Biotechnol. Biochem. 71, 1724-1730.

Galagan, J.E., Calvo, S.E., Borkovich, K.A., Selker, E.U., Read, N.D., Jaffe, D., FitzHugh, W., Ma, L.J., Smirnov, S., Purcell, S., Rehman, B., Elkins, T., Engels, R., Wang, S., Nielsen, C.B., Butler, J., Endrizzi, M., Qui, D., Ianakiev, P., Bell-Pedersen, D., Nelson, M.A., Werner-Washburne, M., Selitrennikoff, C.P., Kinsey, J.A., Braun, E.L., Zelter, A., Schulte, U., Kothe, G.O., Jedd, G., Mewes, W., Staben, C., Marcotte, E., Greenberg, D., Roy, A., Foley, K., Naylor, J., Stange-Thomann, N., Barrett, R., Gnerre, S., Kamal, M., Kamvysselis, M., Mauceli, E., Bielke, C., Rudd, S., Frishman, D., Krystofova, S., Rasmussen, C., Metzenberg, R.L., Perkins, D.D., Kroken, S., Cogoni, C., Macino, G., Catcheside, D., Li ,W., Pratt, R.J., Osmani, S.A., DeSouza, C.P., Glass, L., Orbach, M.J., Berglund, J.A., Voelker, R., Yarden, O., Plamann, M., Seiler, S., Dunlap, J., Radford, A., Aramayo, R., Natvig, D.O., Alex, L.A., Mannhaupt, G., Ebbole, D.J., Freitag, M., Paulsen, I., Sachs, M.S., Lander, E.S., Nusbaum, C., Birren, B., 2003. The genome sequence of the filamentous fungus Neurospora crassa. Nature 422, 859-868.

Galagan, J.E., Calvo, S.E., Cuomo, C., Ma, L.J., Wortman, J.R., Batzoglou, S., Lee, S.I., Baştürkmen, M., Spevak, C.C., Clutterbuck, J., Kapitonov, V., Jurka, J., Scazzocchio, C., Farman, M., Butler, J., Purcell, S., Harris, S., Braus, G.H., Draht, O., Busch, S., D'Enfert, C., Bouchier, C., Goldman, G.H., Bell-Pedersen, D., Griffiths-Jones, S., Doonan, J.H., Yu, J., Vienken, K., Pain, A., Freitag, M., Selker, E.U., Archer, D.B., Peñalva, M.A., Oakley, B.R., Momany, M., Tanaka, T., Kumagai, T., Asai, K., Machida, M., Nierman, W.C., Denning, D.W., Caddick, M., Hynes, M., Paoletti, M., Fischer, R., Miller, B., Dyer, P., Sachs, M.S., Osmani, S.A., Birren, B.W., 2005. Sequencing of Aspergillus nidulans and comparative analysis with A. fumigatus and A. oryzae. Nature 438, 1105-1115.

Garciadeblas, B., Rubio, F., Quintero, F.J., Bañuelos, M.A., Haro, R., Rodríguez-Navarro, A., 1993. Differential expression of two yeast genes encoding isoforms of the ATPase involved in sodium efflux in Saccharomyces cerevisiae. Mol. Gen. Genet. 236, 363-368. 
Gardiner, D.M., Howlett, B.J., 2005. Bioinformatic and expression analysis of the putative gliotoxin biosynthetic gene cluster of Aspergillus fumigatus. FEMS Microbiol. Lett. 248, 241-248.

Garreau, H., Hasan, R.N., Renault, G., Estruch, F., Boy-Marcotte, E., Jacquet, M., 2000. Hyperphosphorylation of Msn2p and Msn4p in response to heat shock and the diauxic shift is inhibited by cAMP in Saccharomyces cerevisiae. Microbiology 146, 2113-2120.

Gasch, A.P., Spellman, P.T., Kao, C.N., Carmel-Harel, C., Eisen, M.B., Storz, G., Botstein, D., Brown, P.O., 2000. Genomic expression programs in the response of yeast cells to environmental changes. Mol. Biol. Cell 11, 4241-4257.

Gasch, A.P., 2007. Comparative genomics of the environmental stress response in ascomycete fungi. Yeast 24, 961-976.

Gene Ontology Consortium, 2001. Creating the gene ontology resource: design and implementation. Genome Res. 11, 1425-1433.

Goldman, G.H., Kafer, E., 2004. Aspergillus nidulans as a models system to characterize the DNA damage response in eukaryotes. Fungal Genet. Biol. 41, 428-442.

Gottlieb, D., Heideman, W., Saba, J.D., 1999. The DPL1 gene is involved in mediating the response to nutrient deprivation in Saccharomyces cerevisiae. Mol. Cell. Biol. Commun. $1,66-71$.

Gouka, R.J., Punt, P.J., van den Hondel, C.A., 1997. Efficient production of secreted proteins by Aspergillus: progress, limitation and prospects. Appl. Microbiol. Biotechnol. 47, 1-11.

Görner, W., Durchschlag, E., Martinez-Pastor, M.T., Estruch, F., Ammerer, G., Hamilton, B., Ruis, H., Schüller, C., 1998. Nuclear localization of the C2H2 zinc finger protein Msn2p is regulated by stress and protein kinase A activity. Genes Dev. 12, 586-597.

Graessle, S., Dangl, M., Haas, H., Mair, K., Trojer, P., Brandtner, E.M., Walton, J.D., Loidl, P., Brosch, G., 2000. Characterization of two putative histone deacetylase genes from Aspergillus nidulans. Biochim. Biophys. Acta 1492, 120-126.

Greenall, A., Hadcroft, A.P., Malakasi, P., Jones, N., Morgan, B.A., Hoffman, C.S., Whitehall, S.K., 2002. Role of fission yeast Tup1-like repressors and Prr1 transcription factor in response to salt stress. Mol. Biol. Cell 13, 2977-2989.

Guillemette, T., van Peij, N.N., Goosen, T., Lanthaler, K., Robson, G.D., van den Hondel, C.A., Stam, H., Archer, D.B., 2007. Genomic analysis of the secretion stress response in the enzyme-producing cell factory Aspergillus niger. BMC Genomics 8, Article No.: 158.

Guo, J., Polymenis, M., 2006. Dcr2 targets Ire1 and downregulates the unfolded protein response in Saccharomyces cerevisiae. EMBO Rep. 7, 1124-1127. 
Hagiwara, D., Asano, Y., Marui, J., Furukawa, K., Kanamaru, K., Kato, M., Abe, K., Kobayashi, T., Yamashino, T., Mizuno, T., 2007a. The SskA and SrrA response regulators are implicated in oxidative stress responses of hyphae and asexual spores in the phosphorelay signaling network of Aspergillus nidulans. Biosci. Biotechnol. Biochem. 71, 1003-1014.

Hagiwara, D., Matsubayashi, Y., Marui, J., Furukawa, K., Yamashino, T., Kanamaru, K., Kato, M., Abe, K., Kobayashi, T., Mizuno, T., 2007b. Characterization of the NikA histidine kinase implicated in the phosphorelay signal transduction of Aspergillus nidulans, with special reference to fungicide responses. Biosci. Biotechnol. Biochem. 71, 844-847.

Hahn, J.S., Thiele, D.J., 2002. Regulation of the Saccharomyces cerevisiae Slt2 kinase pathway by the stress-inducible sdp1 dual specificity phosphatase. J. Biol. Chem. 277, 21278-21284.

Han, K.H., Prade, R.A., 2002. Osmotic stress-coupled maintenance of polar growth in Aspergillus nidulans. Mol. Microbiol. 43, 1065-1078.

He, X.J., Fassler, J.S., 2005. Identification of novel Yap1p and Skn7p binding sites involved in the oxidative stress response of Saccharomyces cerevisiae. Mol. Microbiol. 58, 14541467.

Hicks, J., Lockington, R.A., Strauss, J., Dieringer, D., Kubicek, C.P., Kelly, J., Keller, N., 2001, RcoA has pleitropic effects on Aspergillus nidulans cellular development. Mol. Microbiol. 39, 1482-1493.

Hisada, H., Sano, M., Hata, Y., Abe, Y., Machida, M., 2008. Deletion of the catalaseencoding gene (catB) promoter from Aspergillus oryzae. Biosci. Biotechnol. Biochem. 72, 48-53.

Hohmann, S., 2002. Osmotic stress signaling and osmoadaptation in yeasts. Microbiol. Mol. Biol. Rev. 66, 300-372.

Horan, S., Bourges, I., Meunier, B., 2006. Transcriptional response to nitrosative stress in Saccharomyces cerevisiae. Yeast 23, 519-535.

Hromatka, B.S., Noble, S.M., Johnson, A.D., 2005. Transcriptional response of Candida albicans to nitric oxide and the role of the YHB1 gene in nitrosative stress and virulence. Mol. Biol. Cell 16, 4814-4826.

Jones, I.G., Fairhurst, V., Sealy-Lewis, H.M., 2001. ADHII in Aspergillus nidulans is induced by carbon starvation stress. Fungal Genet. Biol. 32, 33-43. 
Jones, M.G., 2007. The first filamentous fungal genome sequences: Aspergillus leads the way for essential everyday resources or dusty museum specimens? Microbiology 153, 1-6.

Joseph, J.D., Heitman, J., Means, A.R., Molecular cloning and characterization of Aspergillus nidulans cyclophilin B. Fungal Genet. Biol. 27, 55-66.

Joshi, T., Xu, D., 2007. Quantitive assessment of relationship between sequence similarity and function similarity. BMC Genomics 8, Article No. 222.

Juvvadi, P.R., Kuroki, Y., Arioka, M., Nakajima, H., Kitamoto, K., 2003. Functional analysis of the calcineurin-encoding gene cnaA from Aspergillus oryzae: evidence for its putative role in stress adaptation. Arch. Microbiol. 179, 416-422.

Kapoor, M., Curle, C.A., Runham, C., 1995. The hsp70 gene family of Neurospora crassa: cloning, sequence analysis, expression, and genetic mapping of the major stress-inducible member. J. Bacteriol. 177, 212-221.

Kasuya, T., Nakajima, H., Kitamoto, K., 1999. Cloning and characterization of the bipA gene encoding ER chaperone BIP from Aspergillus oryzae. J. Biosci. Bioeng. 88, 472-478.

Kawasaki, L., Wysong, D., Diamond, R., Aguirre, J., 1997. Two divergent catalase genes are differentially regulated during Aspergillus nidulans development and oxidative stress. J. Bacteriol. 179, 3284-3292.

Kawasaki, L., Sánchez, O., Shiozaki, K., Aguirre, J., 2002. SakA MAP kinase is involved in stress signal transduction, sexual development and spore viability in Aspergillus nidulans. Mol. Microbiol. 45, 1153-1163.

Kennedy, E.J., Pillus, L., Ghosh, G., 2005. Pho5p and newly identified nucleotide pyrophosphatases/phosphodiesterases regulate extracellular nucleotide phosphate metabolism in Saccharomyces cerevisiae. Eukaryot. Cell 4, 1892-1901..

Kim, H.G., Park, H.J., Kang, H.J., Lim, H.W., Kim, K., Park, E.H., Ahn, K., Lim, C.J., 2005. The Schizosaccharomyces pombe gene encoding $\gamma$-glutamyltranspeptidase I is required by non-fermentable carbon sources and nitrogen starvation. J. Microbiol. 43, 44-48.

Kim, J.H., Yu, J., Mahoney, N., Chan, K.L., Molyneux, R.J., Varga, J., Bhatnagar, D., Cleveland, T.E., Nierman, W.C., Campbell, B.C., 2008. Int. J. Food Microbiol. 122, 4960 .

Kimata, Y., Ishiwata-Kimata, Y., Yamada, S., Kohno, K., 2006. Yeast unfolded protein response pathway regulates expression of genes for antioxidative stress and for cell surface proteins. Genes Cells 11, 59-69. 
Kimata, Y., Ishiwata-Kimata, Y., Ita, T., Hirata, A., Suzuki, T., Oikawa, D., Takeuchi, M., Kohno, K., 2007. Two regulatory steps of ER-stress sensor Ire1 involving its cluster formation and interaction with unfolded proteins. J. Cell Biol. 179, 75-86.

Krantz, M., Becit, E., Hohmann, S., 2006a. Comparative genomics of the HOG-signalling system in fungi. Curr. Genet. 49, 137-151.

Krantz, M., Becit, E., Hohmann, S., 2006b. Comparative analysis of HOG pathway proteins to generate hypotheses for functional analysis. Curr. Genet. 49, 152-165.

Krems, B., Charizanis, C., Entian, K.D., 1996. The response regulator-like protein Pos9/Skn7 of Saccharomyces cerevisiae is involved in oxidative stress resistance. Curr. Genet. 29:327-334.

Kubicek, C.P., Karaffa, L., 2006. Organic acids. In: Ratledge, C., Kristiansen, B. (Eds.). Basic Biotechnology, Cambridge University Press, Cambridge, pp. 359-380.

Kuchin, S., Vyas, V.K., Carlson, M., 2002. Snf1 protein kinase and the repressors Nrg1 and Nrg2 regulate FLO11, haploid invasive growth, and diploid pseudohyphal differentiation. Mol. Cell. Biol. 22, 3994-4000.

Kumada, K., Su, S., Yanagida, M., Toda, T., 1995. Fission yeast TRP-family protein nuc2 is required for G1-arrest upon nitrogen starvation and is an inhibitor of septum formation. $\mathrm{J}$. Cell Sci. 108, 895-905.

Lamarre, C., Ibrahim-Granet, O., Du, C., Calderone, R., Latgé, J.P., 2007. Characterization of the SKN7 ortholog of Aspergillus fumigatus. Fungal Genet. Biol. 44, 682-690.

La Valle, R., Bromuro, C., Ranucci, L., Muller, H.M., Crisanti, A., Cassone, A., 1995. Molecular cloning and expression of a 70-kilodalton heat shock protein of Candida albicans. Infect. Immun. 63, 4039-4045.

Lee, K., Ebbole, D.J., 1998. Tissue-specific repression of starvation and stress response of the Neurospora crassa con-10 gene is mediated by RCO1. Fungal Genet. Biol. 23, 269-278.

Lee, J., Godon, C., Lagniel, G., Spector, D., Garin, J., Labarre, J., Toledano, M.B., 1999. Yap1 and Skn7 control two specialized oxidative stress response regulons in yeast. J. Biol. Chem. 274, 16040-16046.

Lessing, F., Kniemeyer, O., Wozniok, I., Loeffler, J., Kurzai, O., Haertl, A., Brakhage, A.A., 2007. The Aspergillus fumigatus transcriptional regulator AfYap1 represents the major regulator for defense against reactive oxygen intermediates but is dispensable for pathogenicity in an intranasal mouse infection model. Eukaryot. Cell 6, 2290-2302. 
Li, D.M., Gurkovska, V., Sheridan, M., Calderone, R., Chauhan, N., 2004. Studies on the regulation of the two-component histidine kinase gene CHK1 in Candida albicans using the heterologous lacZ reporter gene. Microbiology 150, 3305-3313.

Li, S., Ault, A., Malone, C.L., Raitt, D., Dean, S., Johnson, L.H., Deschenes, R.J., Fassler, J.S., 1998. The yeast histidine kinase, $\operatorname{Sln} 1 \mathrm{p}$, mediates phosphotransfer to two response regulators, Ssk1p and Skn7p. EMBO J. 17, 6952-6962.

Li, S., Dean, S., Li, Z., Horecka, J., Deschenes, R.J., Fassler, J.S., 2002. The eukaryotic twocomponent histidine kinase $\operatorname{Sin} 1 \mathrm{p}$ regulates $\mathrm{OCH} 1$ via the transcription factor $\mathrm{Skn} 7 \mathrm{p}$. Mol. Biol. Cell 13, 412-424.

Lin, H., Nguyen, P., Vancura, A., 2002. Phospholipase C interacts with Sgd1p and is required for expression of GPD1 and osmoresistance in Saccharomyces cerevisiae. Mol. Genet. Genomics 267, 313-320.

Liu, L., Zeng, M., Hausladen, A., Heitman, J., Stamler, J.S., 2000. Protection from nitrosative stress by yeast flavohemoglobin. Proc. Natl. Acad. Sci. USA 97, 4672-4676.

Lombraña, M., Moralejo, F.J., Pinto, R., Martín, J.F., 2004. Modulation of Aspergillus awamori thaumatin secretion by modification of bipA gene expression. Appl. Environ. Microbiol. 70, 5145-5152.

Longo, V.D., 2003. The Ras and Sch9 pathways regulate stress resistance and longevity. Exp. Gerontol. 38, 807-811.

Lu, J.M., Deschenes, R:J:, Fassler, J.S., 2003. Saccharomyces cerevisiae histidine phosphotransferase Ypd1p shuttles between the nucleus and cytoplasm for SLN1dependent phosphorylation of Ssk1p and Skn7p. Eukaryot. Cell 2, 1304-1314.

Machida, M., Asai, K., Sano, M., Tanaka, T., Kumagai, T., Terai, G., Kusumoto, K., Arima, T., Akita, O., Kashiwagi, Y., Abe, K., Gomi, K., Horiuchi, H., Kitamoto, K., Kobayashi, T., Takeuchi, M., Denning, D.W., Galagan, J.E., Nierman, W.C., Yu, J., Archer, D.B., Bennett, J.W., Bhatnagar, D., Cleveland, T.E, Fedorova, N.D., Gotoh, O., Horikawa, H., Hosoyama, A., Ichinomiya, M., Igarashi, R., Iwashita, K., Juvvadi, P.R., Kato, M., Kato, Y., Kin, T., Kokubun, A., Maeda, H., Maeyama, N., Maruyama, J., Nagasaki, H., Nakajima, T., Oda, K., Okada, K., Paulsen, I., Sakamoto, K, Sawano, T, Takahashi, M., Takase, K., Terabayashi, Y., Wortman, J.R., Yamada, O., Yamagata, Y., Anazawa, H., Hata, Y., Koide, Y., Komori, T., Koyama, Y., Minetoki, T., Suharnan, S., Tanaka, A., Isono, K., Kuhara, S., Ogasawara. N., Kikuchi, H., 2005. Genome sequencing and analysis of Aspergillus oryzae. Nature 438, 1157-1161. 
MacKenzie, D.A., Guillemette, T., Al-Sheikh, H., Watson, A.J., Jeenes, D.J., Wongwathanarat, P., Dunn-Coleman, N.S., van Peij, N., Archer, D.B., 2005. UPRindependent dithiothreitol stress-induced genes in Aspergillus niger. Mol. Genet. Genomics. 274, 410-418.

Mapes, J., Ota, I.M., 2004. Nbp2 targets the Ptc1-type 2C Ser/Thr phosphatase to the HOG MAPK pathway. EMBO J.23, 302-311.

Márquez, J.A., Pascual-Ahuir, A., Proft, M., Serrano, R., 1998. The Ssn6-Tup1 repressor complex of Saccharomyces cerevisiae is involved in the osmotic induction of HOGdependent and -independent genes. EMBO J. 17, 2543-2553.

Mattison, C.O., Ota, I.M., 2000. Two protein tyrosine phosphatases, Ptp2 and Ptp3, modulate the subcellular localization of the Hog1 MAP kinase in yeast. Genes Dev. 14, 129-1235.

Mewes, H.W., Albermann, K., Bähr, M., Frishman, D., Gleissner, A., Hani, J., Heumann, K., Kleine, K., Maierl, A., Oliver, S.G., Pfeiffer, F., Zollner, A., 1997. Overview of the yeast genome. Nature 387, 7-65.

Meyer, V., Damveld, R.A., Arentshorst, M., Stahl, U., van den Hondel, C.A., Ram, A.F., 2007. Survival in the presence of antifungals: genome-wide expression profiling of Aspergillus niger in response to sublethal concentrations of caspofungin and fenpropimorph. J. Biol. Chem. 282, 32935-32948.

Millar, J.B., Buck, V., Wilkinson, M.G., 1995. Pyp1 and Pyp2 PTPases dephosphorylate an osmosensing MAP kinase controlling cell size at division in fission yeast. Genes Dev. 9, 2117-2130.

Monge, R.A., Román, E., Nombela, C., Pla, J., 2006. The MAP kinase signal transduction network in Candida albicans. Microbiology 152, 905-912.

Moralejo, F.J., Watson, A.J., Jeenes, D.J., Archer, D.B., Martín, J.F., 2001. A defined level of protein disulfide isomerase expression is required for optimal secretion of thaumatin by Aspergillus awamori. Mol. Genet. Genomics 266, 246-253.

Morgan, B.A., Banks, G.R., Toone, W.M., Raitt, D., Kuge, S., Johnston, L.H., 1997. The Sko7 response regulator controls gene expression in the oxidative stress response of the budding yeast Saccharomyces cerevisiae. EMBO J. 16, 1035-1044.

Mori, K., Kawahara, T., Yoshida, H., Yanagi, H., Yura, T., 1996. Signalling from endoplasmic reticulum to nucleus: transcription factor with a basic-leucine zipper motif is required for the unfolded protein-response pathway. Genes Cells 1, 803-817. 
Mori, K., Ogawa, N., Kawahara, T., Yanagi, H., Yura, T., 1998. Palindrome with spacer of one nucleotide is characteristic of the cis-acting unfolded protein response element of Saccharomyces cerevisiae. J. Biol. Chem. 273, 9912-9920.

Moskvina, E., Schuller, C., Maurer, C.T., Mager, W.H., Ruis, H., 1998. A search in the genome of Saccharomyces cerevisiae for genes regulated via stress response elements. Yeast 14, 1040-1050.

Mulder, H.J., Saloheimo, M., Penttilä, M., Madrid, S.M., 2004. The transcription factor HACA mediates the unfolded protein response in Aspergillus niger, an dup-regulates its own transcription. Mol. Genet. Genomics 271, 130-140.

Mulder, H.J., Nikolaev, I., Madrid, S.M., 2006. HACA, the transcriptional activator of the unfolded protein response (UPR) in Aspergillus niger, binds to partly palindromic UPR elements of the consensus sequence 5'-CAN(G/A)NTGT/GCCT-3'. Fungal Genet. Biol. $43,560-572$.

Nadin-Davis, S.A., Nasim, A., 1990. Schizosaccharomyces pombe rasl and byrl are functionally related genes of the ste family that affect starvation-induced transcription of mating-type genes. Mol. Cell. Biol. 10, 549-560.

Nakagawa, C.W., Yamada, K., Mutoh, N., 2000. Role of Atf1 and Pap1 in the induction of the catalase gene of fission yeast Schizosaccharomyces pombe. 127, 233-238.

Nakamichi, N., Yanada, H., Aiba, H., Aoyama, K., Ohmiya, R., Mizuno, T., 2003. Characterization of the Prr1 response regulator with special reference to sexual development in Schizosaccharomyces pombe. 67, 547-555.

Nakajima, K., Asakura, T., Maruyama, J., Motita, Y., Oike, H., Shimizu-Ibuka, A., Misaka, T., Sorimachi, H., Arai, S., Kitamoto, K., Abe, K., 2006. Extracellular production of neoculin, a sweet-tasting heterodimeric protein with taste-modifying activity, by Aspergillus oryzae. Appl. Environ. Microbiol. 72, 3716-3723.

Nakashima, A., Hasegawa, T., Mori, S., Ueno, M., Tanaka, S., Ushimaru, T., Sato, S., Uritani, M., 2006. A starvation-specific serine protease gene, isp $6^{+}$, is involved in both autophagy and sexual development in Schizosaccharomyces pombe. Curr. Genet. 49, 403-413.

Malavazi, I., Savoldi, M., Di Mauro, S.M., Menck, C.F., Harris, S.D., Goldman, M.H., Goldman, G.H., 2006. Transcriptome analysis of Aspergillus nidulans exposed to camptothecin-induced DNA damage. Eukaryot. Cell 5, 1688-1704.

Malavazi, I., Savoldi, M., da Silva Ferreira, M.E., Soriani, F.M., Bonato, P.S., de Souza Goldman, M.H., Goldman, G.H., 2007. Transcriptome analysis of the Aspergillus 
nidulans AtmA (ATM, Ataxia-Telangiectasia mutated) null mutant. Mol. Microbiol. 66, 74-99.

Navarro-Garcia, F., Sánchez, M., Pla, J., Nombela, C., 1995. Functional characterization of the $M K C 1$ gene of Candida albicans, which encodes a mitogen-activated protein kinase homolog related to cell integrity. Mol. Cell. Biol. 15, 2197-2206.

Ngiam, C., Jeenes, D.J., Punt, P.J., van den Hondel, C.A., Archer, D.B., 2000. Characterization of a foldase, protein disulfide isomerase $\mathrm{A}$, in the protein secretory pathway of Aspergillus niger. Appl. Environ. Microbiol. 66, 775-782.

Nierman, W.C., Pain. A., Anderson. M.J., Wortman, J.R., Kim, H.S., Arroyo, J., Berriman, M., Abe, K., Archer, D.B., Bermejo, C., Bennett, J., Bowyer, P., Chen, D., Collins, M., Coulsen, R., Davies, R., Dyer, P.S., Farman, M., Fedorova, N., Fedorova, N., Feldblyum, T.V., Fischer, R., Fosker, N., Fraser, A., García, J.L., García, M.J., Goble, A., Goldman, G.H., Gomi, K., Griffith-Jones, S., Gwilliam, R., Haas, B., Haas, H., Harris, D., Horiuchi, H., Huang, J., Humphray, S., Jiménez, J., Keller, N., Khouri, H., Kitamoto, K., Kobayashi, T., Konzack, S., Kulkarni, R., Kumagai, T., Lafon, A., Latgé, J.P., Li, W., Lord, A., Lu, C., Majoros, W.H., May, G.S., Miller, B.L., Mohamoud, Y., Molina, M., Monod, M., Mouyna, I., Mulligan, S., Murphy, L., O'Neil, S., Paulsen, I., Peñalva, M.A., Pertea, M., Price, C., Pritchard, B.L., Quail, M.A., Rabbinowitsch, E., Rawlins, N., Rajandream, M.A., Reichard, U., Renauld, H., Robson, G.D., Rodriguez de Córdoba, S., Rodríguez-Peña, J.M., Ronning, C.M., Rutter, S., Salzberg, S.L., Sanchez, M., SánchezFerrero, J.C., Saunders, D., Seeger, K., Squares, R., Squares, S., Takeuchi, M., Tekaia, F., Turner, G., Vazquez de Aldana, C.R., Weidman, J., White, O., Woodward, J., Yu, J.H., Fraser, C., Galagan, J.E., Asai, K., Machida, M., Hall, N., Barrell, B., Denning, D.W., 2005. Genomic sequence of the pathogenic and allergenic filamentous fungus Aspergillus fumigatus. Nature 438, 1151-1156.

Noguchi, R., Banno, S., Ichikawa, R., Fukumori, F., Ichiishi, A., Kimura, M., Yamaguchi, I., Fujimura, M., 2007. Identification of OS-2 MAP kinase-dependent genes induced in response to osmotic stress, antifungal agent fludioxonil, and heat shock in Neurospora crassa. Fungal Genet. Biol. 44, 208-218.

Noventa-Jordão, M.A., Couto, R.M., Goldman, M.H., Aguirre, J., Iver, S., Caplan, A., Terenzi, H.F., Goldman, G.H., 1999. Catalase activity is necessary for heat-shock recovery in Aspergillus nidulans germlings. Microbiology 145, 3229-3234.

Noventa-Jordão, M.A., do Nascimento, A.M., Goldman, M.H.S., Terenzi, H.F., Goldman, G.H., 2000. Molecular characterization of ubiquitin genes from Aspergillus nidulans: 
mRNA expression on different stress and growth conditions. Biochim. Biophys. Acta 1490, 237-244.

Ohmiya, R., Kato, C., Yamada, H., Aiba, H., Mizuno, T., 1999. A fission yeast gene (ppr $1^{+}$) that encodes a response regulator implicated in oxidative stress response. J. Biochem. 125, 1061-1066.

Okamura, K., Kimata, Y., Higashio, H., Tsuru, A., Kohno, K., 2000, Dissociation ofKAr2p/BiP from an ER sensory molecule, Ire1p, triggers the unfolded protein response in yeast. Biochem. Biophys. Res. Commun. 279, 445-450.

O'Rourke, S.M., Herskowitz, I., O'Shea, E.K., 2002. Yeasts go the whole HOG for the hyperosmotic response. Trends Genet. 18, 405-412.

Ostermann, J., Horwich, A.L., Neupert, W., Hartl, F.U., 1989. Protein folding in mitochondria requires complex formation with hsp60 and ATP hydrolysis. Nature 341, 125-130.

Parlati, F., Dignard, D., Bergeron, J.J., Thomas, D.Y., 1995. The calnexin homologue $c n x 1^{+}$ in Schizosaccharomyces pombe, is an essential gene which can be complemented by its soluble ER domain. EMBO J. 14, 3064-3072.

Payne, G.A., Nierman, W.C., Wortman, J.R., Pritchard, B.L., Brown, D., Dean, R.A., Bhatnagar, D., Cleveleand, T.E., Machida, M., Yu, J., 2006. Whole genome comparison of A. flavus and A. oryzae. Med. Mycol. 44, S9-S11

Pel, H.J., de Winde, J.H., Archer, D.B., Dyer, P.S., Hofmann, G., Schaap, P.J., Turner, G., de Vries, R.P., Albang, R., Albermann, K., Andersen, M.R., Bendtsen, J.D., Benen, J.A., van den Berg, M., Breestraat, S., Caddick, M.X., Contreras, R., Cornell, M., Coutinho, P.M., Danchin, E.G., Debets, A.J., Dekker, P., van Dijck, P.W., van Dijk, A., Dijkhuizen, L., Driessen, A.J., d'Enfert, C., Geysens, S., Goosen, C., Groot, G.S., de Groot, P.W., Guillemette, T., Henrissat, B., Herweijer, M., van den Hombergh, J.P., van den Hondel, C.A., van der Heijden, R.T., van der Kaaij, R.M., Klis, F.M., Kools, H.J., Kubicek, C.P., van Kuyk, P.A., Lauber, J., Lu, X., van der Maarel, M.J., Meulenberg, R., Menke, H., Mortimer, M.A., Nielsen, J., Oliver, S.G., Olsthoorn, M., Pal, K., van Peij, N.N., Ram, A.F., Rinas, U., Roubos, J.A., Sagt, C.M., Schmoll, M., Sun, J., Ussery, D., Varga, J., Vervecken, W., van de Vondervoort, P.J., Wedler, H., Wösten, H.A., Zeng, A.P., van Ooyen, A.J., Visser, J., Stam, H., 2007. Genome sequencing and analysis of the versatile cell factory Aspergillus niger CBS 513.88. Nat. Biotechnol. 25, 221-231.

Peng, Z., Wang, W., Schettino, A., Leung, B., McLeod, M., 2003. Inactivation of Ran1/Pat1 kinase bypasses the requirement for high-level expression of mei2 during fission yeast meiosis. Curr. Genet. 43, 178-185. 
Peterbauer, C.K., Litscher, D., Kubicek, C.P., 2002. The Trichoderma atroviride seb1 (stress response element binding) gene encodes an AGGGG-binding protein which is involved in the response to high osmolarity stress. Mol. Genet. Genomics 268, 223-231.

Pócsi, I., Prade, R.A., Penninckx, M.J., 2004. Glutathione, altruistic metabolite in fungi. Adv. Microb. Physiol. 49, 1-76.

Pócsi, I., Miskei, M., Karányi, Z., Emri, T., Ayoubi, P., Pusztahelyi, T., Balla, G., Prade, R.A., 2005. Comparison of gene expression signatures of diamide, $\mathrm{H}_{2} \mathrm{O}_{2}$ and menadione exposed Aspergillus nidulans cultures - linking genome-wide transcriptional changes to cellular physiology. BMC Genomics 6, Article No. 182

Posas, F., Wurgler-Murphy, S.M., Maeda, T., Witten, E.A., Thai, T.C., Saito, H., 1996. Yeast HOG1 MAP kinase cascade is regulated by a multistep phosphorelay mechanism in the SLN1-YPD1-SSK1 “two-component” osmosensor. Cell 86, 865-875.

Posas, F., Saito, H., 1998. Activation of the yeast SSK2 MAP kinase kinase kinase by the SSK1 two-component response regulator. EMBO J. 17, 1385-1394.

Poustka, A.J., Groth, D., Henning, S., Thamm, S., Cameron, A., Beck, A., Reinhardt, R., Herwig, R., Panopoulou, G., Lehrach, H., 2003. Generation, annotation, evolutionary analysis, and database integration of 20,000 unique sea urchin EST clusters. Genome Res. 13, 2736-2746.

Proft, M., Pascual-Ahuir, A., de Nadal, E., Ariňo, J., Serrano, R., Posas, F., 2001. Regulation of the Sko1 transcriptional repressor by the Hog1 MAP kinase in response to oxidative stress. EMBO J. 20, 1123-1133.

Punt, P.J., van Geremen, I.A., Drint-Kuijvenhoven, J., Hessing, J.G.M., van MuijlwijkHarteveld, G.M., Beijersbergen, A., Verrips, C.T., van den Hondel, C.A., 1998. Analysis of the role of the gene bipA, encoding the major endoplasmic reticulum chaperone protein in the secretion of homologous and heterologous proteins in black Aspergilli. Appl. Microbiol. Biotechnol. 50, 447-454.

Raitt, D.C., Johnson, A.L., Erkine, A.M., Makino, K., Morgan, B., Gross, D.S., Johnston, L.H., 2000. The Skn7 response regulator of Saccharomyces cerevisiae interacts with Hsf1 in vivo and is required for the induction of heat shock genes by oxidative stress. Mol. Biol. Cell 11, 2335-2347.

Reiser, V., Ruis, H., Ammerer, G., 1999. Kinase-dependent nuclear export opposes stressinduced nuclear accumulation and retention of Hog1 mitogen-activated protein kinase in the budding yeast Saccharomyces cerevisiae. Mol. Biol. Cell 10, 1147-1161. 
Rementeria, A., López-Molina, N., Ludwig, A., Vivanco, A.B., Bikandi, J., Pontón, J., Garaizar, J., 2005. Genes and molecules involved in Aspergillus fumigatus virulence. Rev. Iberoam. Micol. 22, 1-23.

Rep, M., Reiser, V., Gartner, U., Thevelein, J.M., Hohmann, S., Ammerer, G., Ruis, H., 1999. osmotic stress-induced gene expression in Saccharomyces cerevisiae requires Msn1p and the novel nuclear factor Hot1p. Mol. Cell. Biol. 19, 5474-5485.

Rep, M., Krantz, M., Thevelein, J.M., Hohmann, S., 2000. The transcriptional response of Saccharomyces cerevisiae to osmotic shock. Hot1p and Msn2p/Msn4p are required for the induction of subsets of high osmolarity. J. Biol. Chem. 275, 8290-8300.

Rep, M., Proft, M., Remize, F., Tamás, M., Serrano, R., Thevelein, J.M., Hohmann, S., 2001. The Saccharomyces cerevisiae Skolp transcription factor mediates HOG pathwaydependent osmotic regulation of a set of genes encoding enzymes implicated in protection from oxidative damage. Mol. Microbiol. 40, 1067-1083.

Reyes, G., Romans, A., Nguyen, C.K., May, G.S., 2006. Novel mitogen-activated protein kinase MpkC of Aspergillus fumigatus is required for utilization of polyalcohol sugars. Eukaryot. Cell 5, 1934-1940.

Riezman, H., 2004. Why do cells require heat shock proteins to survive heat stress? Cell Cycle 3, 61-63.

Román, E., Nombela, C., Pla, J., 2005. The Sho1 adaptor protein links oxidative stress to morphogenesis and cell wall biosynthesis in the fungal pathogen Candida albicans. Mol. Cell Biol. 25, 10611-10627.

Roychowdhury, H.S., Wong, D., Kapoor, M., 1992. hsp80 of Neurospora crassa: cDNA cloning, gene mapping, and studies of mRNA accumulation under stress. Biochem. Cell. Biol. 70, 1356-1367.

Saito, H., Tatebayashi, K., 2004. Regulation of osmoregulatory HOG MAPK cascade in yeast. J. Biochem. 136, 267-272.

Sakamoto, K., Arima, T.H., Iwashita, K., Yamada, O., Gomi, K., Akita, O., 2008. Aspergillus oryzae atfB encodes a transcription factor required for stress tolerance in conidia. Fungal Genet. Biol., 45, 922-932.

Samejima, I., Mackie, S., Fantes, P.A., 1997. Multiple modes of activation of the stressresponse MAP Kinase pathway in fission yeast. EMBO J. 16, 6162-6170.

Sansó, M., Gogol, M., Ayté, J., Seidel, C., Hidalgo, E., 2008. The transcription factors Pcr1 and Atf1 have distinct roles in stress- and Sty1-dependent gene regulation. Eukaryot. Cell $7,826-835$. 
Sato, S., Suzuki, H., Widyastuti, U., Hotta, Y., Tabata, S., 1994. Identification and characterization of genes induced during sexual differentiation in Schizosaccharomyces pombe. Curr. Genet. 26, 31-37.

Seidl, V., Seiboth, B., Karaffa, L., Kubicek, C.P., 2004. The fungal STRE-element-binding protein Seb1 is involved but not essential for glycerol dehydrogenase (gldl) gene expression and glycerol accumulation in Trichoderma atroviride during osmotic stress. Fungal Genet Biol. 41, 1132-1140.

Seppä, L., Hänninen, A.L., Makarow, M., 2004. Upregulation of the Hsp104 chaperone at physiological temperature during recovery from thermal insult. Mol. Microbiol. 52, $217-$ 225.

Saudohar, M., Benčina, M., van de Vondervoort, P.J., Panneman, H., Legiša, M., Visser, J., Ruijter, G.J., 2002. Cyclic AMP-dependent protein kinase is involved in morphogenesis of Aspergillus niger. Microbiology 148, 2635-2645.

Shieh, J.C., Wilkinson, M.G., Buck, V., Morgan, B.A., Makino, K., Millar, J.B., 1997. The Mcs4 response regulator coordinately controls the stress-activated Wak1-Wis1-Sty1 MAP kinase pathway and fission yeast cell cycle. Genes Dev. 11, 1008-1022.

Shiozaki, K., Russel, P., 1995. Counteractive roles of protein phosphatase 2C (PP2C) and MAP kinase kinase homolog in the osmoregulation of fission yeast. EMBO J. 14, 492502.

Shiozaki, K., Russel, P., 1996. Conjugation, meiosis, and the osmotic stress response are regulated by Spc1 kinase through Atf1 transcription factor in fission yeast. Genes Dev. 10, 2276-2288.

Sidrauski, C., Walter, P., 1997. The transmembrane kinase Ire1p is a site-specific endonuclease that initiates mRNA splicing in the unfolded protein response. Cell 90, 1031-1039.

Silberstein, S., Schlenstedt, G., Silver, P.A., Gilmore, R., 1998. A role for the DnaJ homologue Scj1p in protein folding in the yeast endoplasmic reticulum. J. Cell Biol. 143, 921-933.

Skromne, I., Sánchez, O., Aguirre, J., 1995. Starvation stress modulate the expression of the Aspergillus nidulans brlA regulatory gene. Microbiology 141, 21-28.

Suzuki, A., Kanamaru, K., Azuma, N., Kato, M., Kobayashi, T., 2008. GFP-tagged expression analysis revealed that some histidine kinases of Aspergillus nidulans show temporally and spatially different expression during the life cycle. Biosci. Biotechnol. Biochem. 72, 428-434. 
Swoboda, R.K., Bertram, G., Budge, S., Gooday, G.W., Gow, N.A., Brown, A.J., 1995. Structure and regulation of the HSP9O gene from the pathogenic fungus Candida albicans. Infect. Immun. 63, 4506-4514.

Tatebayashi, K., Yamamoto, K., Tanaka, K., Tomida, T., Maruoka, T., Kasukawa, E., Saito, H., 2006. Adaptor functions of Cdc42, Ste50, and Sho1 in the yeast osmoregulatory HOG MAPK pathway. EMBO J. 25, 3033-3044.

Tatebayashi, K., Tanaka, K., Yang, H.Y., Yamamoto, K., Matsushita, Y., Tomida, T., Imai, M., Saito, H. (2007) Transmembrane mucins Hkr1 and Masb2 are putative osmosensors in the SHO1 branch of yeast HOG pathway. EMBO J. 26, 3521-3533.

Teichert, U., Mechler, B., Müller, H., Wolf, D.H., 1989. Lysosomal (vacuolar) proteinases of yeast are essential catalysts for protein degradation, differentiation, and cell survival. J Bio. Chem. 264, 16037-16045.

Teige, M., Scheiki, E., Reiser, V., Ruis, H., Ammerer, G., 2001. Rck2, a member of the calmodulin-protein kinase family, links protein synthesis to high osmolarity MAP kinase signaling in budding yeast. Proc. Natl. Acad. Sci. USA 98, 5625-5630.

Thön, M., Al-Abdallah, Q., Hortschansky, P., Brakhage, A.A., 2007. The thioredoxin system of the filamentous fungus Aspergillus nidulans. J. Biol. Chem. 282, 27259-27269.

Toda, T., Cameron, S., Sass, P., Zoller, M., Scott, J.D., McMullen, B., Hurwitz, M., Krebs, E.G., Wigler, M., 1987. Mol. Cell. Biol. 7, 1371-1377.

Todd, R.B., Hynes, M.J., Andrianapoulos, A., 2006. The Aspergillus nidulans rcoA gene is required for veA-dependent sexual development. Genetics 174, 1685-1688.

Tsuzi, D., Maeta, K., Takatsume, Y., Izawa, S., Inoue, Y., 2004. Regulation of the yeast phospholipid hydroperoxide glutathione peroxidase GPX2 by oxidative stress is mediated by Yap1 and Skn7. FEBS Lett., 565, 148-154.

Tung, H.Y., Wang, W., Chan, C.S., 1995. Regulation of chromosome segregation by Glc8p, a structural homolog of mammalian inhibitor 2 that functions as both an activator and an inhibitor of yeast protein phosphatase 1. Mol. Cell. Biol. 15, 6064-6074.

Ullmann, B.D., Myers, H., Chiranand, W., Lazzell, A.L., Zhao, Q., Vega, L.A., Lopez-Ribot, J.L., Gardner, P.R., Gustin, M.C., 2004. Inducible defense mechanism against nitric oxide in Candida albicans. Eukaryot. Cell 3, 715-723.

Valkonen, M., Ward, M., Wang, H., Pentillä, M., Saloheimo, M., 2003. Improvement of foreign-protein production in Aspergillus niger var. awamori by constitutive induction of the unfolded-protein response. Appl. Environ. Microbiol. 69, 6979-6986. 
van Gemeren, I.A., Punt, P.J., Drint-Kuijvenhoven, A., Broekhuijsen, M.P., van't Hoog, A., Beijersbergen, A., Verrips, C.T., van den Hondel, C.A., 1997. The ER chaperone encoding blpA gene of black Aspergilli is induced by heat shock and unfolded proteins. Gene 198, 43-52.

van Gemeren, I.A., Beijersbergen, A., van den Hondel, C.A., Verrips, C.T., 1998. Expression and secretion of defined cutinase variants by Aspergillus awamori. Appl. Environ. Microbiol. 64, 2794-2799.

Vargas-Pérez, I., Sánchez, O., Kawasaki, L., Georgellis, D., Aguirre, J., 2007. Response regulators SrrA and SskA are central components of a phosphorelay system involved in stress signal transduction and asexual sporulation in Aspergillus nidulans. Eukaryot. Cell 6, 1570-1583.

Virag, A., Lee, M.P., Si, H., Harris, S.D., 2007. Regulation of hyphal morphogenesis by cdc42 and racl homologues in Aspergillus nidulans. Mol. Microbiol. 66, 1579-1596.

Wagner, I., Arlt, H., van Dyck, L., Langer, T., Neupert, W., 1994. Molecular chaperones cooperate with PIM1 protease in the degradation of misfolded proteins in mitochondria. EMBO J., 13, 5135-5145.

Walia, A., Calderone, R., 2008. The SSK2 MAPKKK of Candida albicans is required for oxidant adaptation in vitro. FEMS Yeast Res. 8, 287-299.

Wang, H., Ward, M., Molecular characterization of a PDI-related gene prpA in Aspergillus niger var. awamori. Curr. Genet. 37, 57-64.

Wang, L.Y., Shiozaki, K., 2006. The fission yeast stress MAPK cascade regulates the $p m p 3^{+}$ gene that encodes a highly conserved plasma membrane protein. FEBS Lett. 580, 24092413.

Warmka, J., Hanneman, J., Lee, J., Amin, D., Ota, I., 2001. Ptc1, a type 2C Ser/Thr phosphatase, inactivates the HOG pathway by dephosphorylating the mitogen-activated protein kinase Hog1. Mol. Cell. Biol. 21, 51-60.

Wei, H., Requena, N., Fischer, R., 2003. The MAPKK kinase SteC regulates conidiophore morphology and is essential for heterokaryon formation and sexual development in the homothallic fungus Aspergillus nidulans. Mol. Microbiol. 47, 1577-1588.

Wilkinson, M.G., Samuels, M., Takeda, T., Toone, W.M., Shieh, J.C., Toda, T., Millar, J.B., Jones, N., 1996. The Atf1 transcription factor is a target for the Sty1 stress-activated MAP kinase pathway in fission yeast. Genes Dev. 10:2289-2301. 
Wolschek, M.F., Kubicek, C.P., 1997. The filamentous fungus Aspergillus niger contains two "differentially regulated" trehalose-6-phosphate synthase-encoding genes, tpsA and tpsB. J. Biol. Chem. 272, 2729-2735.

Wood, V., Gwilliam, R., Rajandream, M.A., Lyne, M., Lyne, R., Stewart, A., Sgouros, J., Peat, N., Hayles, J., Baker, S., Basham, D., Bowman, S., Brooks, K., Brown, D., Brown, S., Chillingworth, T., Churcher, C., Collins, M., Connor, R., Cronin, A., Davis, P., Feltwell, T., Fraser, A., Gentles, S., Goble, A., Hamlin, N., Harris, D., Hidalgo, J., Hodgson, G., Holroyd, S., Hornsby, T., Howarth, S., Huckle, E.J., Hunt, S., Jagels, K., James, K., Jones, L., Jones, M., Leather, S., McDonald ,S., McLean, J., Mooney, P., Moule, S., Mungall, K., Murphy, L., Niblett, D., Odell, C., Oliver, K., O'Neil, S., Pearson, D., Quail, M.A., Rabbinowitsch, E., Rutherford, K., Rutter, S., Saunders, D., Seeger, K., Sharp, S., Skelton, J., Simmonds, M., Squares, R., Squares, S., Stevens, K., Taylor, K., Taylor, R.G., Tivey, A., Walsh, S., Warren, T., Whitehead, S., Woodward, J., Volckaert, G., Aert, R., Robben, J., Grymonprez, B., Weltjens, I., Vanstreels, E., Rieger, M., Schäfer, M., Müller-Auer, S., Gabel, C., Fuchs, M., Düsterhöft, A., Fritz, C., Holzer, E., Moestl, D., Hilbert, H., Borzym, K., Langer, I., Beck, A., Lehrach, H., Reinhardt, R., Pohl, T.M., Eger, P., Zimmermann, W., Wedler, H., Wambutt, R., Purnelle, B., Goffeau, A., Cadieu, E., Dréano, S., Gloux, S., Lelaure, V., Mottier, S., Galibert, F., Aves, S.J., Xiang, Z., Hunt, C., Moore, K., Hurst, S.M., Lucas, M., Rochet, M., Gaillardin, C., Tallada, V.A., Garzon, A., Thode, G., Daga, R.R., Cruzado, L., Jimenez, J., Sánchez, M., del Rey, F., Benito, J., Domínguez, A., Revuelta, J.L., Moreno, S., Armstrong, J., Forsburg, S.L., Cerutti, L., Lowe, T., McCombie, W.R., Paulsen, I., Potashkin, J., Shpakovski, G.V., Ussery, D., Barrell, B.G., Nurse, P., 2002. The genome sequence of Schizosaccharomyces pombe. Nature 415, 871-880.

Wortman, J.R., Fedorova, N., Crabtree, J., Joardar, V., Maiti, R., Haas, B.J., Amedeo, P., Lee, E., Angiuoli, S.V., Jiang, B., Anderson, M.J., Denning, D.W., White, O.R., Nierman, W.C., 2006. Whole genome comparison of the A. fumigatus family. Med. Mycol. 44, S3S7.

Xu, Z., Lance, B., Vargas, C., Arpinar, B., Bhandarkar, S., Kraemer, E., Kochut, K.J., Miller, J.A., Wagner, J.R., Weise, M.J., Wunderlich, J.K., Stringer, J., Smulian, G., Cushion, M., Arnold, J., 2003. Mapping by sequencing the Pneumocystis genome using the ordering DNA sequences V3 tool. Genetics 163, 1299-1313. 
Xue, T., Nguyen, K., Romans, A., May, G.S., 2004. A mitogen-activated protein kinase that senses nitrogen regulates conidial germination and growth in Aspergillus fumigatus. Eukaryot. Cell 3, 557-560.

Yamada, K., Nakagawa, C.W., Mutoh, N., 1999. Schizosaccharomyces pombe homologue of glutathione peroxidase, which does not contain selenocysteine, is induced by several stresses and works as an antioxidant. Yeast 15, 1125-1132.

Yoshida, Y., Ogura, Y., Hasunuma, K., 2006. Interaction of nucleoside diphosphate kinase and catalases for stress and light responses in Neurospora crassa. FEBS Lett. 580, 32823286.

Young, C., Mapes, J., Hanneman, J., Al-Zarban, S., Ota, I., 2002. Role of Ptc2 type 2C Ser/Thr phosphatase in yeast high-osmolarity glycerol pathway inactivation. Eukaryot. Cell 1, 1032-1040.

Zarrinpar, A., Park, S.H., Lim, W.A., 2003. Optimization of specificity in a cellular protein interaction network by negative selection. Nature 426, 676-680. 
Tables

Table 1. Stress-response proteins annotated in different aspergilli

\begin{tabular}{|c|c|c|c|c|c|c|c|}
\hline Species & $\begin{array}{c}\text { Osmotic } \\
\text { stress }\end{array}$ & $\begin{array}{c}\text { Oxidative } \\
\text { stress }\end{array}$ & $\begin{array}{c}\text { Thermal stress and } \\
\text { unfolded protein } \\
\text { response }\end{array}$ & Starvation & $\begin{array}{l}\text { DNA } \\
\text { repair }\end{array}$ & $\begin{array}{l}\text { Other } \\
\text { stress }\end{array}$ & $\begin{array}{l}\text { Stress- } \\
\text { response } \\
\text { proteins }^{\mathrm{a}}\end{array}$ \\
\hline A. nidulans & 133 & 108 & 85 & 37 & 172 & 73 & 486 \\
\hline A. clavatus & 130 & 102 & 85 & 38 & 174 & 77 & 484 \\
\hline A. flavus & 143 & 126 & 94 & 46 & 172 & 77 & 520 \\
\hline A. fumigatus & 126 & 102 & 84 & 40 & 169 & 72 & 471 \\
\hline A. niger & 117 & 113 & 73 & 32 & 142 & 50 & 428 \\
\hline A. oryzae & 146 & 123 & 90 & 47 & 167 & 74 & 515 \\
\hline A. terreus & 134 & 123 & 83 & 41 & 172 & 76 & 503 \\
\hline N. fischeri & 134 & 124 & 88 & 38 & 179 & 73 & 501 \\
\hline Aspergillus & & & & & & & \\
\hline $\begin{array}{c}\text { species } \\
\text { altogether }^{\mathrm{a}}\end{array}$ & 1063 & 921 & 682 & 319 & 1347 & 572 & 3908 \\
\hline
\end{tabular}

a - One protein may be placed in several groups of stress response proteins and, hence, the annotated 3908 proteins appeared 4904 times in the six stress protein groups (Supplementary Tables 1-8). 
Table 2.

Annotated elements and targets of SskA and SrrA response regulator-dependent osmotic and oxidative stress response regulatory pathways in the aspergilli.

\begin{tabular}{|c|c|c|c|c|c|c|c|c|c|}
\hline \multirow{2}{*}{$\begin{array}{l}\text { Physiological } \\
\text { function }\end{array}$} & \multirow{2}{*}{$\begin{array}{c}\text { Yeast stress- } \\
\text { response } \\
\text { proteins }^{\mathrm{a}}\end{array}$} & \multicolumn{8}{|c|}{ Orthologues and putative orthologues in the aspergilli } \\
\hline & & $\begin{array}{l}\text { A. } \\
\text { nidulans }\end{array}$ & A. clavatus & A. flavus & $\begin{array}{l}\text { A. } \\
\text { fumigatus }\end{array}$ & A. niger & A. oryzae & A. terreus & N. fischeri \\
\hline \multirow{5}{*}{$\begin{array}{c}\text { Sho1p-like } \\
\text { stress sensing } \\
\text { and signalling } \\
\text { branch }^{\mathrm{b}}\end{array}$} & Sho1p & $\begin{array}{l}\text { AN7698 } \\
\text { (ShoA) }\end{array}$ & ACLA_012130 & AFL2G_06338 & Afu5g08420 & e_gw1_14.461 & AO090701000763 & ATEG_08258 & NFIA_008170 \\
\hline & Cdc42p & $\begin{array}{l}\text { AN7487.3 } \\
\text { (ModA) }\end{array}$ & ACLA_068600 & AFL2G_09325 & Afu2g05740 & An02g14200 & AO090001000693 & ATEG_06763 & NFIA_082460 \\
\hline & Cla4p & AN8836.3 & ACLA_009160 & - & Afu5g05900 & est_GWPlus_C_160600 & AO090009000674 & ATEG_09444 & NFIA_037230 \\
\hline & Ste20p & AN2067.3 & ACLA_089970 & AFL2G_02712 & Afu2g04680 & est_GWPlus_C_40790 & AO090003000267 & ATEG_06035 & NFIA_081350 \\
\hline & Ste11p & $\begin{array}{l}\text { AN2269.3 } \\
\text { (SteC) } \\
\end{array}$ & ACLA_009750 & AFL2G_10116 & Afu5g06420 & An17g01280 & AO090009000610 & ATEG_09389 & NFIA_036710 \\
\hline \multirow{7}{*}{ Histidine kinase } & Sln1p & $\begin{array}{l}\text { AN1800.3 } \\
\text { (TcsB) }\end{array}$ & ACLA 094100 & AFL2G 04890 & $\begin{array}{l}\text { Afu2g00660 } \\
\text { (TcsB) }\end{array}$ & - & AO090011000093 & ATEG 07365 & NFIA 032940 \\
\hline & Mak1* & AN3101.3 & ACLA 040370 & AFL2G 00704 & Afu3g12530 & e gw1 2.30 & AO090005000715 & ATEG 04140 & NFIA 064770 \\
\hline & Mak2* & AN3102.3 & ACLA_040380 & AFL2G_00703 & Afu3g12550 & fge1_pg_C_2000617 & AO090005000714 & ATEG_04139 & NFIA_064760 \\
\hline & & - & - & - & - & - & - & - & NFIA_072160 \\
\hline & Mak2* & $\begin{array}{l}\text { AN5296.3 } \\
\text { (TesA) }\end{array}$ & ACLA_083970 & AFL2G_04130 & $\begin{array}{l}\text { Afu6g10240 } \\
\text { (Fos-1) }\end{array}$ & e_gw1_6.721 & AO090023000259 & ATEG_02495 & NFIA_055960 \\
\hline & & - & - & - & - & e_gw1_4.144 & - & - & - \\
\hline & Mak2* & $\begin{array}{l}\text { AN4479.3 } \\
\text { (NikA) } \\
\end{array}$ & ACLA 090930 & AFL2G 08246 & $\begin{array}{l}\text { Afu2g03560 } \\
\text { (Bos1) }\end{array}$ & fge1 pg C 5000177 & AO090120000228 & ATEG 09534 & NFIA 035930 \\
\hline $\begin{array}{c}\text { Histidine- } \\
\text { containing } \\
\text { phosphotransfer } \\
\text { intermediate }\end{array}$ & Ypd1p & $\begin{array}{l}\text { AN2005 } \\
\text { (YpdA) }\end{array}$ & ACLA_049490 & AFL2G_01854 & Afu4g10280 & An04g06570 & AO090003001194 & ATEG_00699 & NFIA_105780 \\
\hline \multirow{3}{*}{$\begin{array}{l}\text { Response } \\
\text { regulator }\end{array}$} & Ssk1p & $\begin{array}{l}\text { AN7697.3 } \\
\text { (SskA) }\end{array}$ & ACLA_012140 & AFL2G_06337 & Afu5g08390 & An03g04670 & AO090701000762 & ATEG_08259 & NFIA_078890 \\
\hline & & - & - & AFL2G_12585 & - & - & - & - & - \\
\hline & Prr1* & $\begin{array}{l}\text { AN3688.3 } \\
\text { (SrrA) }\end{array}$ & ACLA_085770 & AFL2G_02624 & $\begin{array}{l}\begin{array}{l}\text { Afu6g12520 } \\
\text { (afSKN7) }\end{array} \\
\end{array}$ & fge1_pg_C_3000205 & AO090003000363 & ATEG_03268 & NFIA_058480 \\
\hline
\end{tabular}




\begin{tabular}{|c|c|c|c|c|c|c|c|c|c|}
\hline МАРККК & Ssk2p & $\begin{array}{l}\text { AN10153.3 } \\
\text { (SskB) }\end{array}$ & ACLA_024570 & AFL2G_07670 & Afulg10940 & fge1_pg_C_3000791 & AO090038000312 & ATEG_00291 & NFIA_014690 \\
\hline МАРКK & Pbs2p & $\begin{array}{l}\text { AN0931.3 } \\
\text { (PbsB) }\end{array}$ & ACLA_019390 & AFL2G_01045 & Afu1g15950 & est_fge1_pg_C__10308 & AO090005001093 & ATEG_05187 & NFIA_009350 \\
\hline \multirow{2}{*}{ MAPK } & Hog1p & $\begin{array}{l}\text { AN1017.3 } \\
\text { (HogA/SakA) }\end{array}$ & ACLA_011450 & AFL2G_06243 & $\begin{array}{l}\text { Afu1g12940 } \\
\text { (SakA) }\end{array}$ & e_gw1_10.301 & AO090020000466 & ATEG_00489 & NFIA_012610 \\
\hline & $\mathrm{MpkC}^{* *}$ & $\begin{array}{l}\text { AN4668.3 } \\
\text { (MpkC) }\end{array}$ & ACLA_022520 & AFL2G_10858 & $\begin{array}{l}\text { Afu5g09100 } \\
\text { (MpkC) }\end{array}$ & fge1_pg_C_5000454 & AO090701000642 & ATEG_06557 & NFIA_078210 \\
\hline \multirow{4}{*}{$\begin{array}{c}\text { Regulation of } \\
\text { the HOG } \\
\text { pathway }\end{array}$} & Ptp2p, Ptp3p & $\begin{array}{l}\text { AN6982.3 } \\
\text { (PtpA) }\end{array}$ & ACLA_053640 & AFL2G_12456 & Afu4g04710 & e_gw1_8.145 & AO090206000016 & ATEG_02763 & NFIA_028630 \\
\hline & Pyp2* & AN4896.3 & ACLA_038900 & AFL2G_02356 & Afu3g10970 & fge1_pm__C_1000613 & AO090003000651 & ATEG_04624 & NFIA_066280 \\
\hline & Ptc1p & AN6892.3 & ACLA_016330 & AFL2G_08466 & Afu5g13340 & est_fge1_pg_C__80382 & AO090120000479 & ATEG_06173 & NFIA_073700 \\
\hline & Ptc2p, Ptc3p & AN1358.3 & ACLA_026190 & AFL2G_01488 & Afu1g09280 & gw1_3.574 & AO090005001595 & ATEG_08554 & NFIA_016350 \\
\hline \multirow{3}{*}{$\begin{array}{c}\text { Nuclear } \\
\text { importin or } \\
\text { exportin }\end{array}$} & Gsp1p, Gsp2p & $\begin{array}{l}\text { AN5482.3 } \\
\text { (RanA) }\end{array}$ & ACLA_086550 & AFL2G_02536 & Afu6g13300 & An08g10060 & AO090003000454 & ATEG_03365 & NFIA_059220 \\
\hline & Nmd5p & AN6006.3 & ACLA_069050 & AFL2G_05386 & Afu2g10010 & An16g05050 & AO090011000635 & ATEG_04435 & NFIA_085430 \\
\hline & Crm1p & $\begin{array}{l}\text { AN1401.3 } \\
\text { (KapK) }\end{array}$ & ACLA_026800 & AFL2G_01536 & Afu1g08790 & est_GWPlus_C_32422 & AO090005001650 & ATEG_08495 & NFIA_016940 \\
\hline \multirow{8}{*}{$\underset{\text { targets }^{\text {HogA/SakA }}}{\text { Horgen }}$} & Rck2p & AN4483.3 & ACLA_091030 & AFL2G_08251 & Afu2g03490 & An07g07970 & AO090120000235 & ATEG_09539 & NFIA_035840 \\
\hline & Tup1p & $\begin{array}{l}\text { AN6505.3 } \\
\text { (RcoA) }\end{array}$ & ACLA_095390 & AFL2G_05678 & Afu6g05150 & An15g00140 & AO090701000021 & ATEG_05660 & NFIA_051720 \\
\hline & Cус8р & 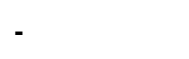 & ACLA_070780 & AFL2G_06816 & Afu2g11840 & est_fge1_pm_C_20065 & AO090026000459 & ATEG_01125 & NFIA_087070 \\
\hline & Atf1* & $\begin{array}{l}\text { AN2911.3 } \\
\text { (AtfA) }\end{array}$ & ACLA_039220 & AFL2G_02323 & Afu3g11330 & An02g07070 & AO090003000685 & ATEG_04664 & NFIA_065970 \\
\hline & Msn2p, Msn4p & $\begin{array}{l}\text { AN1652.3 } \\
\text { (MsnA) }\end{array}$ & ACLA_048440 & AFL2G_04479 & Afu4g09080 & An04g03980 & AO090023000650 & ATEG_05308 & NFIA_107090 \\
\hline & Sgd1p & AN4581.3 & ACLA_092840 & AFL2G_05233 & Afu2g01980 & e_gw1_5.86 & AO090011000468 & ATEG_05716 & NFIA_034350 \\
\hline & Rpd3p & $\begin{array}{l}\text { AN4493.3 } \\
\text { (RpdA) }\end{array}$ & ACLA_091130 & AFL2G_08263 & Afu2g03390 & An07g07850 & AO090012000132 & ATEG_09554 & NFIA_035740 \\
\hline & & - & - & AFL2G_03062 & - & - & - & - & - \\
\hline
\end{tabular}




\begin{tabular}{|c|c|c|c|c|c|c|c|c|c|}
\hline \multirow{10}{*}{ AtfA targets ${ }^{c, d}$} & & AN10982.3 & ACLA_094630 & AFL2G_06033 & Afu2g01320 & fge1_pm_C_11000239 & AO090701000406 & ATEG_08161 & NFIA_033620 \\
\hline & Cta3* & AN1628.3 & ACLA_096890 & AFL2G_04426 & Afu4g09440 & fge1_pm_C_6000111 & AO090023000590 & ATEG_07100 & NFIA_106580 \\
\hline & & AN6642.3 & - & AFL2G_10132 & Afu6g03690 & - & AO090009000591 & ATEG_05265 & NFIA_050200 \\
\hline & Atf1* & $\begin{array}{l}\text { AN2911.3 } \\
\text { (AtfA) }\end{array}$ & ACLA_039220 & AFL2G_02323 & Afu3g11330 & An02g07070 & AO090003000685 & ATEG_04664 & NFIA_065970 \\
\hline & Pyp2* & AN4896.3 & ACLA_038900 & AFL2G_02356 & Afu3g10970 & fge1_pm_C_1000613 & AO090003000651 & ATEG_04624 & NFIA_066280 \\
\hline & Gpd1* & $\begin{array}{l}\text { AN0351.3 } \\
\text { (GfdA) }\end{array}$ & ACLA_032280 & AFL2G_00859 & Afu1g02150 & e_gw1_1.1679 & AO090005000883 & ATEG_04878 & NFIA_022500 \\
\hline & Gpd2* & $\begin{array}{l}\text { AN6792.3 } \\
\text { (GfdB) }\end{array}$ & ACLA_080090 & AFL2G_05589 & Afu2g08250 & fge1_pm_C_6000321 & AO090011000879 & ATEG_02234 & NFIA_083910 \\
\hline & Ctt1* & $\begin{array}{l}\text { AN9339.3 } \\
\text { (CatB) }\end{array}$ & ACLA_062020 & AFL2G_08106 & Afu3g02270 & est_GWPlus_C_12396 & AO090120000068 & ATEG_07477 & NFIA_003430 \\
\hline & $C_{2}+2+2$ & AN2846.3 & ACLA_040140 & AFL2G_00727 & Afu3g12270 & An02g08110 & AO090005000739 & ATEG_04161 & NFIA_065020 \\
\hline & GpX1* & - & - & AFL2G_12085 & - & - & - & - & - \\
\hline \multirow{9}{*}{ SsrA targets ${ }^{c, d}$} & $\operatorname{Trx} 2 p$ & $\begin{array}{l}\text { AN0170.3 } \\
(\text { ThiO/TrxA) }\end{array}$ & ACLA_014400 & AFL2G_06605 & Afu5g11320 & An01g02500 & AO090026000708 & ATEG_07726 & NFIA_075950 \\
\hline & Trr1p & $\begin{array}{l}\text { AN3581.3 } \\
\text { (TrxB/TrxR) }\end{array}$ & ACLA_051990 & AFL2G_10383 & Afu4g12990 & An01g08570 & AO090009000289 & ATEG_03181 & NFIA_103360 \\
\hline & & AN10982.3 & ACLA_094630 & AFL2G_06033 & Afu2g01320 & fge1_pm_C_11000239 & AO090701000406 & ATEG_08161 & NFIA_033620 \\
\hline & Cta3* & AN1628.3 & ACLA_096890 & AFL2G_04426 & Afu4g09440 & fge1_pm_C_6000111 & AO090023000590 & ATEG_07100 & NFIA_106580 \\
\hline & & AN6642.3 & - & AFL2G_10132 & Afu6g03690 & - & AO090009000591 & ATEG_05265 & NFIA_050200 \\
\hline & $O \operatorname{ch} 1 p$ & AN4716.3 & ACLA_011950 & AFL2G_08225 & Afu5g08580 & e_gw1_5.365 & AO090120000208 & ATEG_05779 & NFIA_078700 \\
\hline & Ctt1p & $\begin{array}{l}\text { AN9339.3 } \\
(\text { CatB })^{f}\end{array}$ & ACLA_062020 & AFL2G_08106 & Afu3g02270 & est_GWPlus_C_12396 & AO090120000068 & ATEG_07477 & NFIA_003430 \\
\hline & Gpx1p, Gpx2p & AN2846.3 & ACLA_040140 & AFL2G_00727 & Afu3g12270 & An02g08110 & AO090005000739 & ATEG_04161 & NFIA_065020 \\
\hline & Чрхір, Чрхгр & - & - & AFL2G_12085 & - & - & - & - & - \\
\hline Sgd1p target ${ }^{c, d}$ & Gpd1p & $\begin{array}{l}\text { AN0351.3 } \\
\text { (GfdA) }\end{array}$ & ACLA_032280 & AFL2G_00859 & Afu1g02150 & e_gw1_1.1679 & AO090005000883 & ATEG_04878 & NFIA_022500 \\
\hline $\begin{array}{l}\text { Smp1p } \\
\text { target }^{\mathrm{c}, \mathrm{d}}\end{array}$ & Stl1p & AN9168.3 & ACLA_064920 & AFL2G_10659 & Afu8g05710 & An14g02740 & AO090020000696 & ATEG_01874 & NFIA_098490 \\
\hline
\end{tabular}




\begin{tabular}{|c|c|c|c|c|c|c|c|c|c|}
\hline \multirow{4}{*}{$\underset{\text { targets }^{\text {c,d }}}{\operatorname{MsnA}}$} & Gpd1p & $\begin{array}{l}\text { AN0351.3 } \\
\text { (GfdA) }\end{array}$ & ACLA_032280 & AFL2G_00859 & Afu1g02150 & e_gw1_1.1679 & AO090005000883 & ATEG_04878 & NFIA_022500 \\
\hline & Ald2p & AN9034.3 & ACLA_043350 & AFL2G_06572 & Afu8g02310 & - & AO090026000741 & ATEG_08300 & NFIA_095930 \\
\hline & Gpp2p & $\begin{array}{l}\text { AN1216.3 } \\
\text { (GppA) }\end{array}$ & ACLA_024960 & AFL2G_04374 & Afu1g10570 & fge1_pg_C_3000140 & AO090038000367 & ATEG_00249 & NFIA_015080 \\
\hline & Ctt1p & $\begin{array}{l}\text { AN9339.3 } \\
\text { (CatB) }\end{array}$ & ACLA_062020 & AFL2G_08106 & Afu3g02270 & est_GWPlus_C_12396 & AO090120000068 & ATEG_07477 & NFIA_003430 \\
\hline \multirow{6}{*}{$\underset{\text { targets }^{\mathrm{c}, \mathrm{d}}}{\operatorname{RcoA}}$} & Gpd1p & $\begin{array}{l}\text { AN0351.3 } \\
\text { (GfdA) }\end{array}$ & ACLA_032280 & AFL2G_00859 & Afu1g02150 & e_gw1_1.1679 & AO090005000883 & ATEG_04878 & NFIA_022500 \\
\hline & Ald2p & AN9034.3 & ACLA_043350 & AFL2G_06572 & Afu8g02310 & - & AO090026000741 & ATEG_08300 & NFIA_095930 \\
\hline & Ctt1p & $\begin{array}{l}\text { AN9339.3 } \\
\text { (CatB) }\end{array}$ & ACLA_062020 & AFL2G_08106 & Afu3g02270 & est_GWPlus_C_12396 & AO090120000068 & ATEG_07477 & NFIA_003430 \\
\hline & & AN10982.3 & ACLA_094630 & AFL2G_06033 & Afu2g01320 & fge1_pm_C_11000239 & AO090701000406 & ATEG_08161 & NFIA_033620 \\
\hline & Cta3* & AN1628.3 & ACLA_096890 & AFL2G_04426 & Afu4g09440 & fge1_pm_C_6000111 & AO090023000590 & ATEG_07100 & NFIA_106580 \\
\hline & & AN6642.3 & - & AFL2G_10132 & Afu6g03690 & - & AO090009000591 & ATEG_05265 & NFIA_050200 \\
\hline
\end{tabular}

a - Unless otherwise indicated, S. cerevisiae stress-response proteins are shown. Please note that the homology between the A. nidulans ShoA, YpdA, PtpA, MsnA, AtfA, ThiO/TrxA and GppA and the corresponding S. cerevisiae or S. pombe genes were relatively low, characterized with $E$-values higher than 1E-40 (Table 3). Superscripts ${ }^{*}$ and ${ }^{* *}$ stand for $S$. pombe and A. nidulans stress-response proteins, respectively.

b - The Sho1p-branch of osmotic stress sensing is not functional in A. nidulans.

c - Hypothetical regulations based on yeast stress models.

d - Target proteins are regulated at the level of transcription.

e - Homologies between A. nidulans ThiO/TrxA and A. clavatus (7E-32), A. flavus (6E-39), A. fumigatus (3E-34), A. niger (3E-40), A. oryzae (1E-36), A. terreus (3E-45) and $N$. fischeri (7E-34) orthologous thioredoxins are shown in the parentheses. According to the $E \leq 1 \mathrm{E}-40$ cut-off rule, only thioredoxins of A. nidulans, A. niger and A. terreus are shown in the Supplementary Tables.

f - Verified target (Hagiwara et al., 2007; Vargas-Pérez et al., 2007). 
Table 3

Putative A. nidulans orthologues with relatively low $(E>1 \mathrm{E}-40)$ homology to yeast osmotic and oxidative stress-response proteins

\begin{tabular}{|c|c|c|c|}
\hline Physiological function & $\begin{array}{c}\text { Yeast stress- } \\
\text { response } \\
\text { proteins } \\
\end{array}$ & $\begin{array}{l}\text { Putative } A . \text { nidulans } \\
\text { orthologues }\end{array}$ & $E$-value ${ }^{b}$ \\
\hline \multirow{3}{*}{$\begin{array}{l}\text { Sho1p-like stress sensing and signalling } \\
\text { branch }^{\mathrm{c}}\end{array}$} & Sho1p & AN7698.3 (ShoA) & 9E-37 \\
\hline & Msb2p & AN7041.3 & 1E-18 \\
\hline & Ste50p & AN7252.3 & 6E-17 \\
\hline $\begin{array}{c}\text { Histidine-containing phosphotransfer } \\
\text { intermediate }\end{array}$ & Ypd1p & AN2005.3 (YpdA) ${ }^{d}$ & $5 E-18$ \\
\hline \multirow{2}{*}{ Regulation of the HOG pathway } & Ptp2p & AN6982.3 (PtpA) $)^{e}$ & 3E-32 \\
\hline & Nbp2p & AN3819.3 & 5E-17 \\
\hline \multirow{3}{*}{ SakA/HogA targets ${ }^{\mathrm{f}}$} & Msn2p & AN1652.3 (MsnA) & 1E-16 \\
\hline & Msn4p & AN1652.3 (MsnA) & 2E-17 \\
\hline & Smp1p & AN2984.3 & 1E-25 \\
\hline \multirow{2}{*}{ AtfA targets ${ }^{\mathrm{f}, \mathrm{g}}$} & Atf1* & AN2911.3 (AtfA) & 1E-36 \\
\hline & Pmp3* & AN2312.3 & 9E-13 \\
\hline SrrA target ${ }^{\mathrm{f}, \mathrm{g}}$ & Trx2p & AN0170.3 (ThiO/TrxA) ${ }^{d}$ & 2E-26 \\
\hline MsnA target ${ }^{\mathrm{f}, \mathrm{g}}$ & Gpp2p & AN1216.3 (GppA) & 1E-37 \\
\hline \multirow{4}{*}{ Other stress-response transcription factors } & Yap1p & AN7513.3 & 5E-13 \\
\hline & Sko1p ${ }^{h}$ & AN2911.3 (AtfA) & 1E-09 \\
\hline & Hot1p & - & - \\
\hline & Msn1p & - & - \\
\hline
\end{tabular}

a - Unless otherwise indicated, S. cerevisiae stress-response proteins are shown. Superscripts * stand for $S$. pombe stress-response proteins.

b - E-values are from BLASTP searches performed in the NCBI database (http://blast.ncbi.nlm.nih.gov/Blast.cgi).

c - The Sho1p-branch of osmotic stress sensing is not functional in A. nidulans.

d - Functionality is determined (Furukawa et al., 2005; Vargas-Perez et al., 2007; Thön et al., 2007).

e - The homology between Ptp3p and PtpA (Table 2) was more significant ( $E$-value 4E-42).

$\mathrm{f}$ - Hypothetical regulations based on yeast analogies.

$\mathrm{g}$ - Target proteins are regulated at the level of transcription.

h - BLASTP search for Sko1p orthologues brought up AtfA bZip proteins in all aspergilli with low homologies ( $E$-values 2E-07 - 9E-09). 


\section{Legends to the Figures}

Figure 1. Osmotic and oxidative stress signal generation, signal transduction, and stress response in A. nidulans. Where our knowledge on Aspergillus stress response was limited relevant $S$. cerevisiae and/or $S$. pombe stress response data were taken into consideration. The names of A. nidulans gene products having been identified are printed in red, meanwhile redflamed gene products and red arrows indicate experimentally described and verified stressresponse-related gene products and interactions. Orthologue of yeast Cyc8p protein and ShoA-PbsA protein-protein interaction, which do not exist in A. nidulans, are marked with red Xs. Elements of osmotic stress sensing, signalling and stress response are summarized in Tables 2 and 3. 


\section{Figure 1}

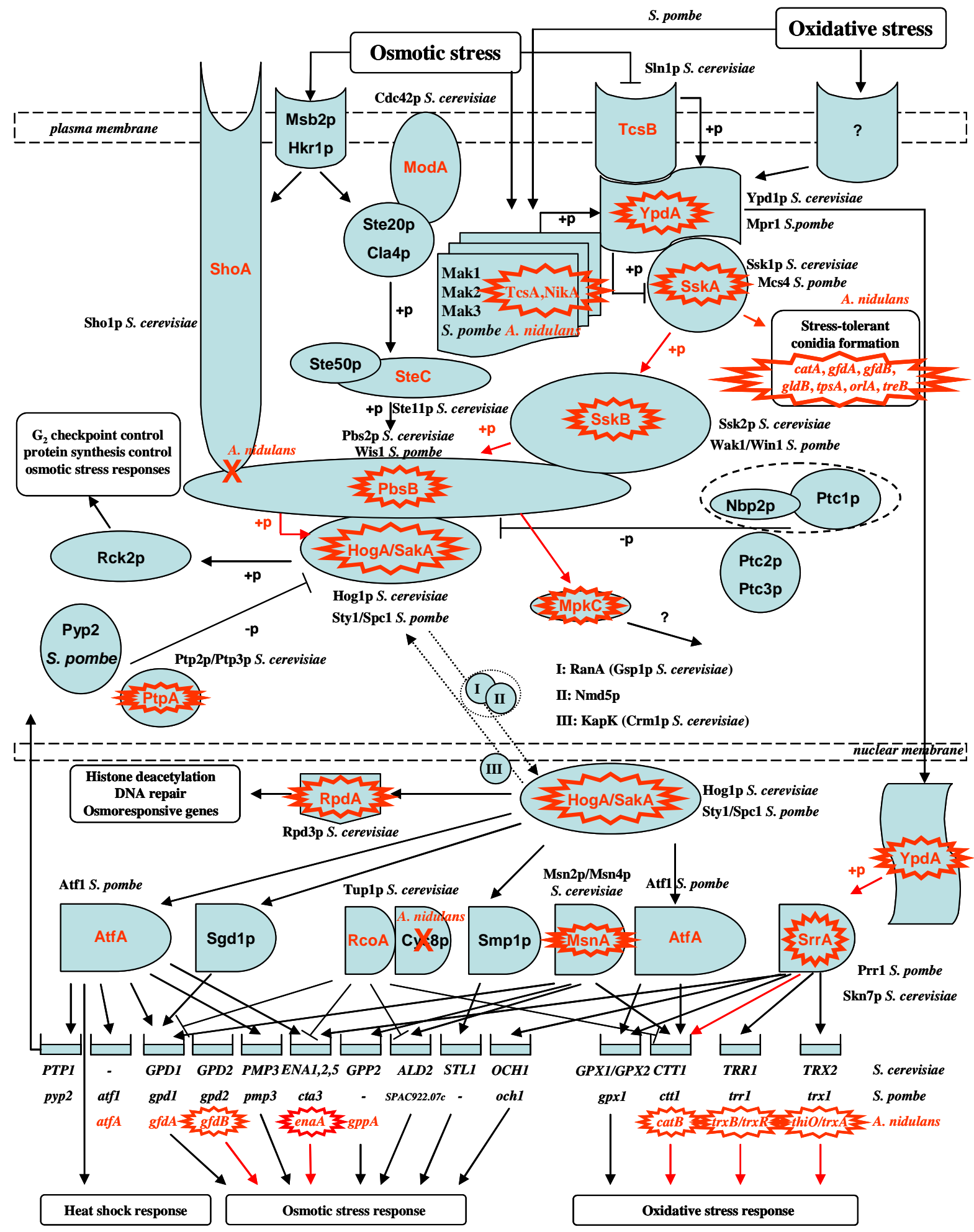

